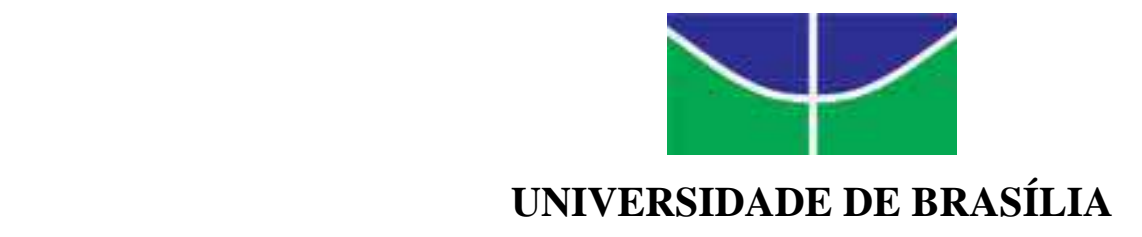

FACULDADE DE ECONOMIA, ADMINISTRAÇÃO, CONTABILIDADE E CIÊNCIA DA INFORMAÇÃO E DOCUMENTAÇÃO (FACE)

ANGELA LIMA

RAIMUNDO COSMO DE LIMA FILHO

O PAPEL DO CESPE/UnB NA SOCIEDADE: PROCESSOS DE PRESTAÇÃO DE SERVIÇOS 
ANGELA LIMA

RAIMUNDO COSMO DE LIMA FILHO

\section{O PAPEL DO CESPE/UnB NA SOCIEDADE: PROCESSOS DE PRESTAÇÃO DE SERVIÇOS}

Monografia apresentada à Faculdade de Economia, Administração, Contabilidade e Ciência da Informação e Documentação - FACE, da Universidade de Brasília, como requisito parcial para obter o grau de Especialista em Gestão Universitária.

Aprovação em 30 de junho de 2008.

\section{BANCA EXAMINADORA}

Profa. Mestre Fernanda Anjos Orientadora
Prof. Doutorando Mamede Said Maia Filho Convidado 


\section{AGRADECIMENTOS}

Ao Ser eterno, que está dentro de todas as formas, como a mais profunda, invisível e indestrutível essência interior.

Ao Professor César Augusto Tibúrcio Silva, ilustre mestre e amigo, que acreditou no programa de desenvolvimento gerencial dos servidores da UnB.

À Professora Fernanda Anjos, pela sabedoria de sua orientação, pela generosidade e verdadeira amizade dispensada durante todo o curso.

Ao Professor Mamede Said Maia Filho, pelo apoio e incentivo ao estudo deste tema, pela sua generosidade e competência.

Ao Prof. Mauro Luiz Rabelo, Diretor-Geral do CESPE/UnB e sua equipe técnica, que apoiaram a idéia do presente estudo.

À amiga Tatiana Farias Moreira, pela inestimável contribuição na tarefa de análise dos dados.

À amiga Sônia Olesko, pela revisão da diagramação.

Ao meu filho Lucas, amor da minha vida, pelo irrestrito apoio e compreensão.

Angela Lima
Aos meus filhos Gabriel e Rafael, fontes de inspiração e iluminação.

Raimundo Cosmo de Lima Filho 


\section{RESUMO}

O presente trabalho trata do processo de prestação de serviços para captação de recursos complementares para a Universidade de Brasília/UnB, o qual envolveu a realização de análise documental e de uma pesquisa que teve como objeto os processos realizados pelo Centro de Seleção e de Promoção de Eventos da UnB - Cespe/UnB. Uma das constatações aponta para o fato de que, apesar de o Cespe/UnB dispor de considerável capacidade de geração de recursos e atualmente ser considerado o maior captador de recursos da Universidade, reconhecido nacionalmente, o modelo de gestão não acompanhou as modernas tecnologias de informação, disponíveis na própria instituição. Os resultados da pesquisa indicam a necessidade de melhorar permanentemente os procedimentos e os instrumentos de gestão com a implantação de uma gestão por processos e plataforma integrada de gestão administrativa.

Palavras-chave: Universidades públicas. Educação superior. FUB. UnB. Cespe/UnB. Sistemas. Captação de Recursos. Prestação de Serviços. Processos e procedimentos. Gestão de Recursos. 


\section{LISTA DE ILUSTRAÇÕES}

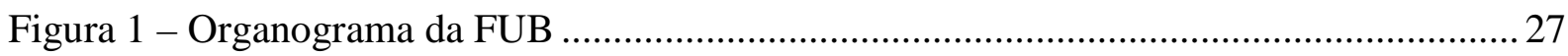

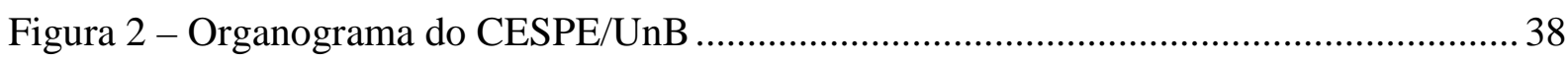

Figura 3 - Contrato de Prestação de Serviços ........................................................................... 46

Figura 4 - Participação de Servidor em Contratos e Projetos ..................................................... 47

Figura 5 - Participação de Servidor em Curso ou Concurso - EVENTOS FUB ....................... 48 


\section{LISTA DE TABELAS}

Tabela 1 - Previsão de acréscimo orçamentário a partir do Decreto nº 6.096/2007 21

Tabela 2 - Respondente 1 - Categoria 1 - Perfil 52

Tabela 3 - Respondente 1 - Pontos fortes e melhorias ........................................................ 53

Tabela 4 - Respondente 2 - Categoria 1 - Perfil ................................................................... 53

Tabela 5 - Respondente 2 - Categoria 2 - Pontos fortes e melhorias ...................................54

Tabela 6 - Respondente 3 - Categoria 1 - Perfil ............................................................... 54

Tabela 7 - Respondente 3 - Categoria 2 - Pontos fortes e melhorias ...................................55

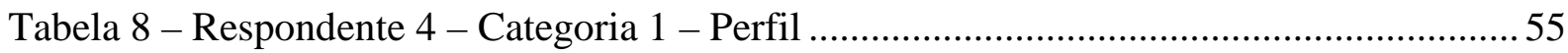

Tabela 9 - Respondente 4 - Categoria 2 - Pontos fortes e melhorias ....................................56

Tabela 10 - Respondente 5 - Categoria 1 - Perfil ................................................................56

Tabela 11 - Respondente 5 - Categoria 2 - Pontos fortes e melhorias ...................................59

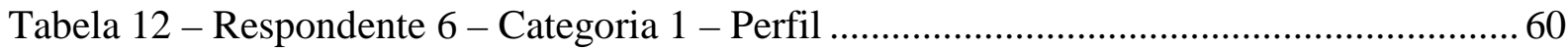

Tabela 13 - Respondente 6 - Categoria 2 - Pontos fortes e melhorias ................................. 60

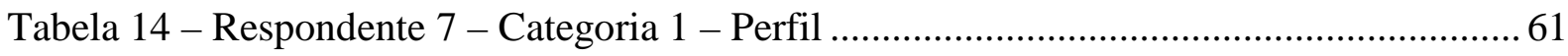

Tabela 15 - Respondente 7 - Categoria 2 - Pontos fortes e melhorias ................................. 62

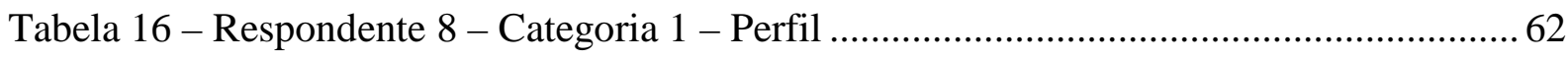

Tabela 17 - Respondente 8 - Categoria 2 - Pontos fortes e melhorias .................................. 63

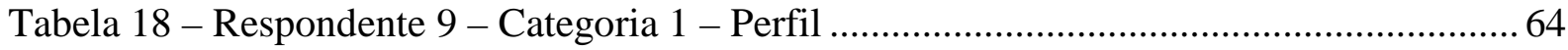

Tabela 19 - Respondente 9 - Categoria 2 - Pontos fortes e melhorias .................................. 64

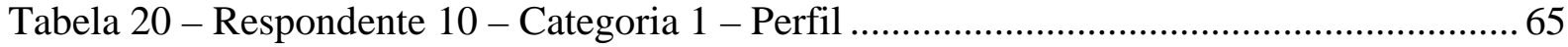

Tabela 21 - Respondente 10 - Categoria 2 - Pontos fortes e melhorias................................ 65

Tabela 22 - Respondente 11 - Categoria 1 - Perfil ...............................................................66

Tabela 23 - Respondente 11 - Categoria 2 - Pontos fortes e melhorias................................. 66

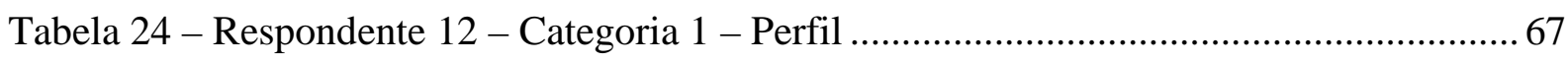

Tabela 25 - Respondente 12 - Categoria 2 - Pontos fortes e melhorias................................ 67

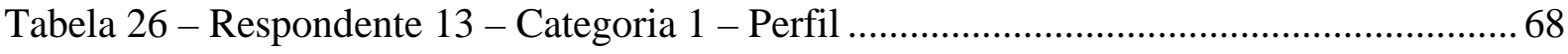

Tabela 27 - Respondente 13 - Categoria 2 - Pontos fortes e melhorias................................. 68 


\section{SUMÁRIO}

1. INTRODUÇÃ

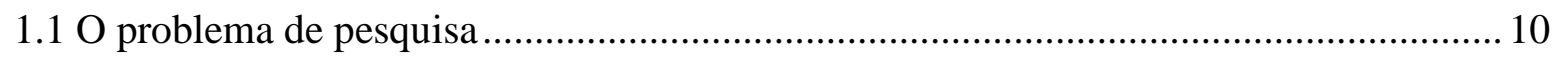

1.2 Definiç̧ão da pergunta da pesquisa ..................................................................... 11

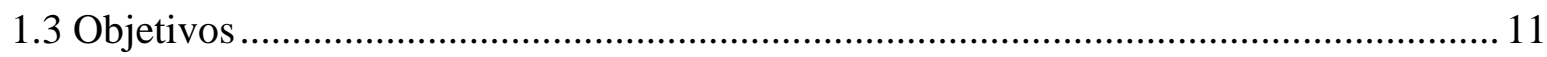

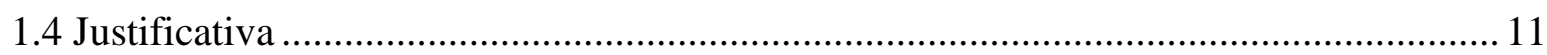

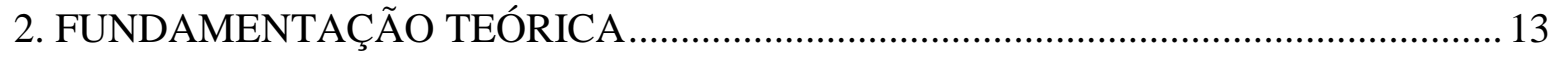

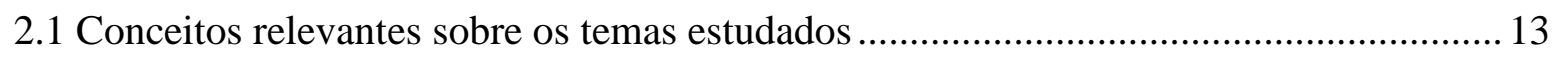

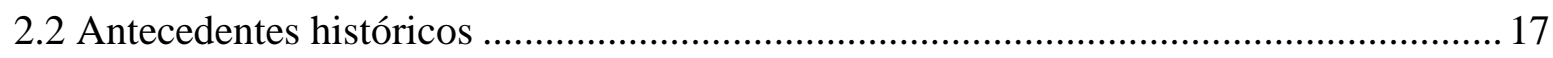

2.3 O Financiamento da Educação Superior no Brasil ..................................................... 19

3. A HISTÓRIA DA FUNDAÇÃO UNIVERSIDADE DE BRASÍLIA ............................22

3.1 Pontos Fortes e Fracos apontados pelos Gestores...................................................... 23

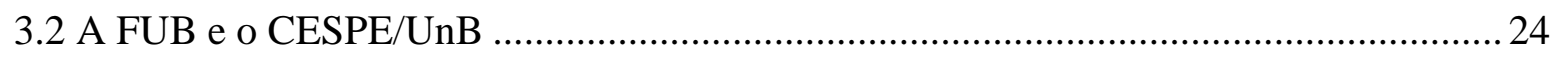

3.3 A história do Centro de Seleção e de Promoção de Eventos (CESPE/UnB) .................. 28

3.4 Os serviços oferecidos pelo CESPE/UnB à sociedade e a captação de recursos

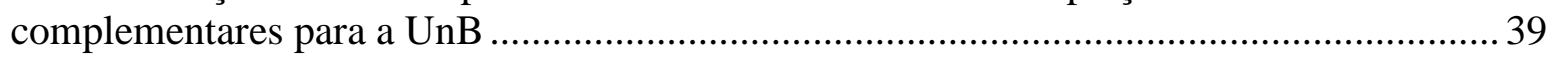

3.5 Fluxo dos procedimentos relativos aos processos seletivos e concursos públicos ..........39

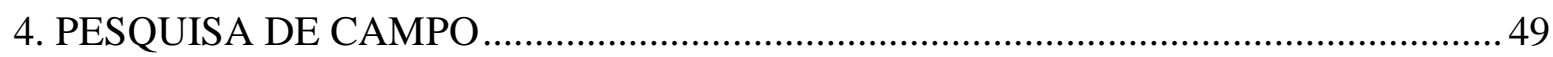

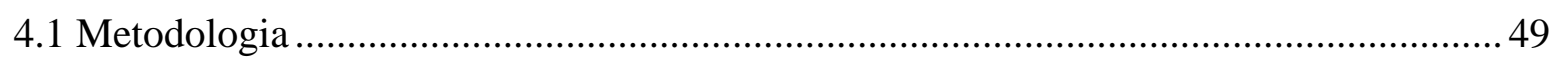

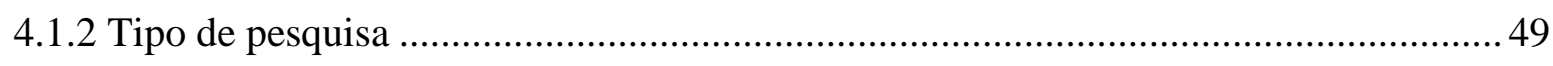

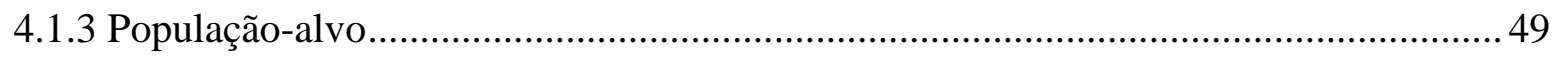

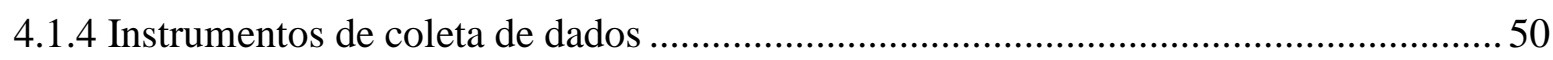

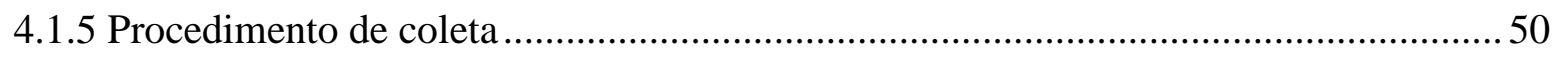

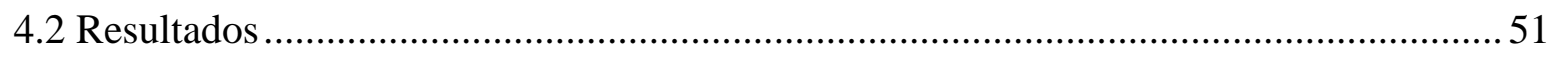

4.2.1 Definição e caracterização da população ............................................................... 51

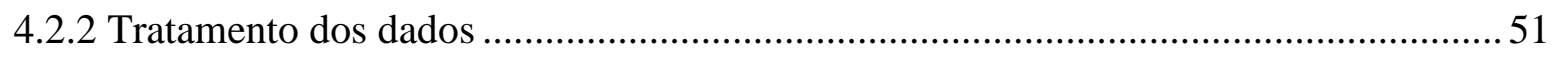

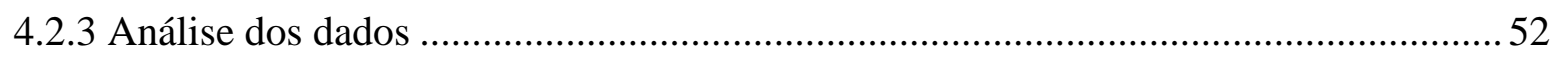

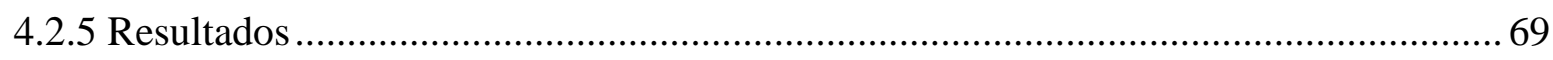

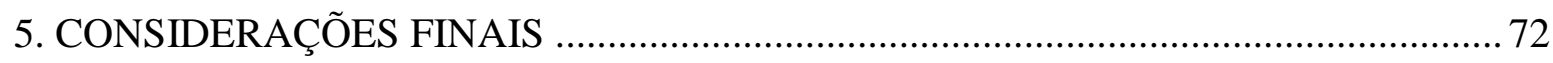

REFERÊNCIAS

ANEXO 


\section{INTRODUÇÃO}

As universidades públicas brasileiras passaram por uma crise institucional financeira em face da descapitalização estatal e da destinação do erário para outros fins de maior apelo junto à sociedade. Conseqüentemente, o Estado não investiu o suficiente na universidade pública, fato agravado pela economia globalizada que impõe modelos que priorizam a busca de soluções na esfera pública mais recorrentes na esfera privada. Assim, a universidade pública, com o intuito de ultrapassar a crise financeira, procurou meios de geração de receitas próprias. Essa busca pelo autofinanciamento não é, no entanto, isenta de defensores e de questionadores, e é geradora de acalorados debates.

Em 1994, as IFES receberam de recursos públicos 0,91\% do PIB brasileiro; em 2002 houve uma redução de 30\%, enquanto no mesmo período, as matrículas nessas instituições aumentaram 37\%. A partir de 2003, com o início do governo Lula, o volume de recursos permaneceu basicamente o mesmo, havendo apenas recuperação de recursos de custeio aos níveis de 1995 (SGUISSARDI, 2006) . Os recursos orçamentários destinados às IFES em 2005 foram de 8,4 bilhões de reais, significando um aumento de 2,29\% em relação a 2004. Em 2006 esse valor foi para 8,9 bilhões de reais (+ 5,04\%); o orçamento de 2007 foi elevado em 15,58\% (BRASIL, 2007b); (BRASIL, 2007c).

A busca pelos recursos financeiros por meio de atividades, como a prestação de serviços, trata-se de um fenômeno global, embora sejam significativamente diferentes suas conseqüências em cada região do mundo. Na Europa, com exceção da Inglaterra, o sistema universitário é quase totalmente público, a universidade, em geral, tem o poder de reduzir o âmbito da descapitalização ao mesmo tempo em que tem desenvolvido a capacidade para gerar receitas próprias por meio do mercado (SANTOS, 2005).

Destarte, as universidades brasileiras buscam alternativas para captação de recursos próprios a fim de complementar as verbas repassadas pelo Governo. A prestação de serviços aos órgãos públicos, organizações e empresas privadas e as ofertas de cursos de especialização e de extensão destacam-se no autofinanciamento das universidades públicas. A Universidade de Brasília (UnB) é uma das instituições que tem maior projeção em recursos diretamente arrecadados. Essa iniciativa é para superar a insuficiência de recursos e garantir a manutenção mínima das atividades de ensino, pesquisa, extensão e de infra-estrutura. 
A evolução da busca de recursos próprios da UnB - geração e distribuição no âmbito da Universidade - vem de longa data. A captação de verbas próprias pela UnB é realizada por vários centros de custos, alguns deles especialmente constituídos para tal fim. No entanto, ao contrário do que ocorre nas Instituições Federais de Ensino Superior (IFES), na UnB as principais fontes arrecadadoras não são as fundações de apoio.

Na verdade, a maior fonte é o Centro de Seleção e de Promoção de Eventos (CESPE/UnB), que celebra contratos e convênios com entidades públicas e privadas, para realizar inúmeras atividades técnicas especializadas, como a elaboração e realização de concursos públicos em todo o país, vestibulares e avaliações educacionais.

Nos últimos anos, ao CESPE/UnB coube o maior percentual de receitas próprias da UnB, ainda que cerca de $85 \%$ dos recursos sejam gastos com a execução das próprias atividades contratadas e com o pagamento de pessoal, conforme Relatório Preliminar de Gestão/2007 - Portal da UnB/SPL.

Outra fonte de receita da UnB é a renda obtida com aluguel de imóveis pertencentes ao patrimônio imobiliário da sua mantenedora, a Fundação Universidade de Brasília (FUB), que também é tida como fonte potencial de arrecadação alternativa em relação às demais IFES. Os recursos captados pela Secretaria de Gestão Patrimonial (SGP) têm correspondido, no entanto, a um pequeno percentual do total das receitas próprias da UnB, uma vez que os imóveis residenciais são alugados a docentes e técnicos administrativos a preços abaixo do mercado, a título de "taxa de ocupação", como forma de atrair e fixar profissionais competentes para garantir o bom funcionamento da universidade.

Outro Centro de Custo que também contribui muito com a arrecadação de recursos próprios é a Editora $\mathrm{UnB}$, todavia, suas receitas são investidas na divulgação de obras de relevância acadêmica, mas de pequeno valor comercial. É, então, fonte e destino de recursos próprios.

A realidade de depauperação da universidade pública levou, por assim dizer, a busca de um quase autofinanciamento. No caso específico da UnB, a dependência de recursos próprios para sua manutenção e desenvolvimento é crescente. Nos últimos cinco anos, os recursos diretamente arrecadados foram equivalentes a mais que o triplo do aportado pelo MEC para despesas correntes (UnB, 2007). 
Essa forma de captação de recursos freqüentemente conta com a participação de servidores docentes e técnico-administrativos da instituição. No debate referente à captação de recursos por meio de prestação de serviços, predominam questões como a de que os instrumentos de captação desses recursos, muitas vezes envolvem complementação salarial e constituem-se em mais um passo para a privatização da universidade pública. No entanto, outros defendem essa forma de captação como uma alternativa para sobrevivência da universidade pública e gratuita.

Segundo Santos (2005, p. 8 e 9), identificam-se três crises vivenciadas pela universidade, que a enfraqueceram aos olhos da sociedade. A crise de hegemonia, que resultava das contradições entre as funções tradicionais da universidade e as que ao longo do século XX lhe tinham vindo a ser atribuídas; a crise de legitimidade, provocada pelo fato de a universidade ter deixado de ser uma instituição consensual, uma vez que ao mesmo tempo em que detém o saber sistematizado sofre a pressão para uma democratização de acesso por parte de classes mais populares. Finalmente, a crise institucional resultava da contradição entre a reivindicação da autonomia na definição dos valores e objetivos da universidade e a pressão crescente para submeter esta última a critérios de eficácia e de produtividade de natureza empresarial ou responsabilidade social. Essas crises foram alguns dos fatores de desprestígio e conseqüente redução de orçamento do Estado.

Um dos reflexos das políticas e das recomendações expressas pelo Banco Mundial (DIAS, 2004) e pelo Banco Interamericano de Desenvolvimento (BID) (VELLOSO, 2000) foi a crescente divulgação de dados que revelariam a universidade pública como perdulária, ineficiente e de custos excessivamente elevados (AMARAL, 2003; CORBUCCI, 2004; VELLOSO, 2005). O corte de verbas públicas foi considerado, pelos governantes, inevitável, principalmente na rubrica de pessoal.

\subsection{0 problema de pesquisa}

Uma das maiores, se não a maior fonte de captação de recursos da UnB, o CESPE, é um objeto de estudo tanto no que se refere ao que esse Centro já tem realizado quanto ao que pode vir a realizar.

Tendo-se isso em mente, pretende-se investigar as formas de prestação de serviços à comunidade e a captação de recursos diretamente pelo CESPE/UnB, mediante a discussão 
do que é a instituição pública FUB, quais as suas finalidades essenciais, levando-se sempre em consideração os aspectos técnicos e jurídicos e seus permissivos legais.

Busca-se, ainda, apontar caminhos para que os gestores do CESPE/UnB possam melhorar continuamente a capacidade para gerar receitas próprias, com segurança jurídica e autonomia, mediante a melhoria contínua dos processos de prestação de serviços.

\subsection{Definição da pergunta da pesquisa}

A intenção deste estudo é responder à pergunta: como funcionam e como melhorar os processos de captação de recursos mediante a prestação de serviços no âmbito do CESPE/UnB, em consonância com a legislação do serviço público?

\subsection{Objetivos}

O objetivo geral do presente trabalho é contribuir para a melhoria contínua dos processos de captação de recursos mediante a prestação de serviços pelo CESPE/UnB, por meio de estudo sistemático e crítico das atividades desse Centro. E tem os seguintes objetivos específicos:

- Identificar os meios de captação de recursos, mediante a prestação de serviços à sociedade;

- Comentar a legislação pertinente;

- Discutir propostas de melhoria dos procedimentos e processos administrativos no âmbito do CESPE/UnB.

\subsection{Justificativa}

Nos últimos anos houve considerável aumento da procura pelos serviços da UnB por parte de diversos órgãos públicos e privados, o que gerou necessidade de se modernizarem processos e procedimentos de captação e gerenciamento de recursos.

A sociedade civil cada vez mais exige que haja controle e transparência na execução de prestação de serviços, notadamente os que são prestados por órgãos de alguma forma ligados ao Estado. Também é exigido pela sociedade que maior eficiência e eficácia estejam presentes na aplicação de recursos captados pelas instituições públicas. Assim, foram 
desenvolvidos vários mecanismos gerenciais pela administração superior da Fundação Universidade de Brasília (FUB).

É neste contexto que o presente trabalho vislumbra buscar a melhoria contínua dos processos de captação de recursos, mediante a prestação de serviços pelo CESPE/UnB, seja na diversificação da captação de recursos, seja no desenvolvimento de novas ferramentas gerenciais.

Trata-se de tema da maior relevância para a UnB, que embora conviva com essa necessidade, ainda não conseguiu sistematizar, em manuais, produção técnica-científica sobre a matéria captação de recursos e prestação de serviços. Fato que confere um caráter de trabalho inédito à monografia.

Alguns autores trataram de parte do tema, alguns estudaram a questão da autonomia universitária, como a Professora Anita Lapa Borges de Sampaio, outros, como os Professores Boaventura e Morin, estudaram a reforma universitária. Outros autores, como Sabo Paes, discutiram profundamente o tema sobre o prisma das Fundações de Apoio. Verifica-se, todavia, que sob a ótica do serviço público, o tema carece de estudos, sobretudo ao que diz respeito à legislação aplicada à matéria.

Assim, embora não se tenha a pretensão de esgotar o tema sobre prestação de serviços pelo CESPE/UnB à sociedade, o caráter interdisciplinar do presente trabalho fica evidenciado pelo estudo da legislação aplicada e também dos procedimentos de gestão administrativa, constituindo-se em possível material de consulta aos gestores públicos interessados.

Partiu-se da hipótese de que a captação de recursos para complementação do orçamento da FUB, por meio de prestação de serviços à comunidade, é perfeitamente legal e necessária à manutenção das atividades da UnB e que o modelo de gestão do CESPE/UnB pode ser constantemente aperfeiçoado, servindo de referência para outras instituições. 


\section{FUNDAMENTAÇÃO TEÓRICA}

Este item elenca, de forma sistematizada, conceitos relevantes sobre os temas estudados na elaboração deste trabalho e a legislação aplicada ao serviço público, à UnB, à prestação de serviços e à captação de recursos. Em seguida, trata-se da gestão da captação de recursos no âmbito do CESPE/UnB.

\subsection{Conceitos relevantes sobre os temas estudados}

Impõe-se para consecução do presente estudo o conhecimento de alguns conceitos relevantes, tais como:

\section{a) Instituição de Ensino Superior Pública}

São Universidades e Instituições de Ensino Superior estruturadas sob a forma de autarquia ou de fundação pública, conforme se depreende do art. $3^{\circ}$, da Lei ${ }^{\circ} 7.596$, de 10 de abril de 1987 (BRASIL, 1987).

Com efeito, as universidades possuem suas finalidades essenciais previstas, de modo expresso, imperativo e incontrastável na Constituição. O art. 207 do texto constitucional impõe às universidades, imediatamente após assegurar sua autonomia didáticocientífica, administrativa e de gestão financeira e patrimonial, o dever de observância ao princípio da indissociabilidade entre ensino, pesquisa e extensão. Por conseguinte, as universidades, no gozo de sua autonomia constitucionalmente assegurada, encontram-se sujeitas à realização, de modo indissociável, do ensino, da pesquisa e da extensão. Se a Constituição defere às universidades ampla autonomia (isto é, uma prerrogativa de autodeterminação, livre decisão e autogoverno) que se projeta sobre todos os aspectos das esferas didático-científica, administrativa e de gestão financeira e patrimonial e, concomitantemente, obriga (isto é, retira de sua livre decisão) a elas apenas a realização indissociável do ensino, da pesquisa e da extensão. Afigura-se forçoso concluir serem essas as três importantes atividades. O caráter imperativo e indissociável da vinculação das universidades - autônomas com respeito à decisão de realizar todas as demais atividades - ao ensino, à pesquisa e à extensão constitui, portanto, a identificação constitucional das finalidades essenciais das universidades e deverá nortear, de modo análogo, a delimitação das atividades delas decorrentes. 


\section{b) Administração Pública}

Administração Pública é conjunto de agentes, órgãos e pessoas jurídicas destinadas à execução das atividades administrativas, que corresponde a todo o aparelhamento de que dispõe o Estado para consecução das políticas traçadas pelo Governo (ALEXANDRINO; PAULO, 2005).

Segundo o saudoso mestre Meirelles (1999, p. 59), em sentido formal, Administração Pública é o conjunto de órgãos instituídos para consecução dos objetivos do Governo e, em sentido material, é o conjunto das funções necessárias aos serviços públicos em geral. Na sua acepção operacional a Administração Pública é o desempenho perene e sistemático, legal e técnico, dos serviços próprios do Estado ou por ele assumidos em benefício da coletividade (MEIRELLES, 1999).

\section{c) Entidade de Administração Direta e Administração Indireta}

Administração Direta é o conjunto de órgãos que integram as pessoas políticas do Estado, aos quais foi atribuída a competência para o exercício, de forma centralizada, de atividades administrativas. São exemplos de entidades estatais da Administração Direta a União, os Estados, o Distrito Federal e os Municípios. Já a Administração Indireta é o conjunto de pessoas administrativas que, vinculadas à Administração Direta, têm a competência para o exercício, de forma descentralizada, de atividades administrativas.

Quanto à legislação, o Decreto-Lei no. 200, de 1967, em seu artigo 4º , estabelece a organização da Administração Pública Federal:

I - a Administração Direta, que se constitui dos serviços integrados na estrutura administrativa da Presidência da República e dos Ministérios;

II - a Administração Indireta, que compreende as seguintes categorias de entidades, dotadas de personalidade jurídica própria:
a) autarquias;
b) empresas públicas;
c) sociedades de economia mista;
d) fundações públicas. (BRASIL, 1967, p.1)

Para o desempenho de suas atribuições, o Estado adota duas formas de organização e atuação administrativas: a centralização e a descentralização. Ocorre a centralização administrativa quando o Estado executa suas tarefas diretamente, por meio dos órgãos e agentes integrantes da Administração Direta. Já a descentralização administrativa ocorre quando o Estado desempenha algumas de suas funções por meio de outras pessoas 
jurídicas. Assim, pressupõem-se duas pessoas jurídicas distintas, de um lado o Estado e de outro a entidade que executará o serviço.

É importante salientar que há duas formas para que o Estado efetive a chamada descentralização administrativa: outorga e delegação. Na outorga o Estado, por meio de lei, cria uma entidade e a ela transfere determinado serviço público. É o que ocorre com as entidades da administração indireta, por exemplo, as autarquias e as fundações públicas.

A descentralização administrativa é efetivada por meio de delegação quando o Estado transfere, por contrato, unicamente a execução de um serviço, para que o ente delegado o preste ao público em seu próprio nome e por sua própria conta e risco. Isto realizado sob a fiscalização do Estado.

d) Autarquias: conceito, criação, natureza jurídica, patrimônio, auto-administração, atividades desenvolvidas, controle judicial, juízo competente, atos e contratos, orçamento, dirigentes, controle de desempenho

Autarquias são entidades administrativas autônomas, criadas por lei específica, com personalidade jurídica de direito público interno, patrimônio próprio e atribuições estatais específicas. O art. $5^{\circ}$, inciso I, do Decreto-Lei n ${ }^{\circ}$ 200, de 1967 assim define autarquia:

Autarquia - o serviço autônomo, criado por lei, com personalidade jurídica, patrimônio e receita próprios para executar atividades típicas da Administração Pública, que requeiram, para seu melhor funcionamento, gestão administrativa e financeira descentralizada. (BRASIL, 1967, p.1)

As autarquias possuem capacidade de auto-administração, o que significa administrar a si próprias segundo as regras constantes da lei que as instituiu.

Os atos praticados pelas autarquias são considerados atos administrativos. Esses atos sujeitam-se ao controle do Poder Judiciário, e têm como juízo competente para julgar suas causas o juízo da Justiça Federal, conforme preceitua o artigo 109, inciso I, da Constituição Federal.

Os contratos celebrados pelas autarquias, em regra, são precedidos de licitação, nos termos do artigo 37, inciso XXI, da Constituição Federal. São considerados contratos administrativos, sujeitando-se ao mesmo regime daqueles celebrados pela Administração Direta. 
Quanto ao orçamento das autarquias, este é idêntico em sua forma àquele das entidades estatais a que pertencem, nos termos do artigo 165 , parágrafo $5^{\circ}$., da Constituição Federal, o que quer dizer que se a autarquia é ligada, por exemplo, ao MEC, seu orçamento configurar-se-á da mesma forma que o do orçamento do MEC.

Os dirigentes das autarquias têm sua forma de investidura prevista na lei instituidora ou estabelecida em seu estatuto. A competência para nomeação é privativa do Presidente da República, nos termos do art. 84, inciso XXV, da Constituição Federal (BRASIL, 1988, p.68).

É importante, ainda, nessa fase preliminar deste estudo, comentar como é feito o controle de desempenho da autarquia. Assim, a entidade estatal que cria uma autarquia exerce sobre ela o chamado controle finalístico, que visa a mantê-la no estrito cumprimento de suas finalidades, previstas na lei instituidora. Não ocorre controle hierárquico, pois não há subordinação entre autarquia e entidade instituidora, de outra forma seria suprimida a autonomia administrativa e financeira de tais entidades. De fato, o nome autarquia (ou sua variante, autarcia) tem como origem o grego, no qual quer dizer o que governa a si mesmo.

\section{e) Fundações Públicas: natureza jurídica e regime jurídico}

Oriunda do Direito Privado, a idéia de fundação caracteriza-se pela atribuição de personalidade jurídica a um determinado patrimônio destinado a um fim específico. A fundação pública é entidade da Administração Indireta, conforme define a Lei no. 7.596, de 10 de abril de 1987:

Art. $2^{\circ}$. São classificadas como fundações públicas as fundações qe passaram a integrar a Administração Federal Indireta, por força do disposto no parágrafo $2^{\circ}$. Do art. $4^{\circ}$. Do Decreto-Lei no. 200, de 25 de fevereiro de 1967, na redação dada pelo Decreto-Lei no. 2.299, de 21 de novembro de 1986.

Art. $3^{\circ}$. As universidades e demais instituições de ensino superior, estruturadas sob a forma de autarquia ou de fundação pública, terão um Plano Único de Classificação e Retribuição de Cargos e Empregos para o pessoal docente e para os servidores técnicos e administrativos, aprovado, em regulamento, pelo Poder Executivo, assegurada a observância do princípio da isonomia salarial e a uniformidade de critérios tanto para ingresso mediante concurso público de provas, ou de provas e títulos, quanto para a promoção e ascensão funcional, com valorização do desempenho e da titulação do servidor. (BRASIL, 1987, p. 1)

Em face do que dispõe a legislação acerca da matéria e entendimento doutrinário dominante, as fundações públicas com personalidade de direito público são, na verdade, segundo os Professores Alexandrino e Paulo (2005, p. 36), espécie do gênero autarquia. Assim, para as fundações públicas são extensíveis às mesmas restrições, prerrogativas e 
privilégios que a ordem jurídica atribui às autarquias, tanto de direito material como de direito processual. Por esta razão se fez necessário o presente estudo preliminar.

\subsection{Antecedentes históricos}

A universidade surgiu no Brasil no século XVII, com a abertura de faculdades isoladas nas capitais, sendo a maioria pertencente aos jesuítas. O sistema universitário só começa a existir de fato no século XX. A primeira universidade do país foi fundada em Manaus (1909) e a experiência não prosperou. Em 1920 foi criada a primeira instituição a se manter como universidade, na cidade do Rio de Janeiro. Em 1930, foi instituído o Estatuto das Universidades Brasileiras que define o objetivo do ensino superior: elevar o nível de cultura geral, estimular a investigação científica e habilitar o cidadão ao exercício de uma profissão. Em 1934, foi criada a Fundação Universidade de São Paulo.

A Constituição de 1937, outorgada por Getúlio Vargas, determinava que a educação superior e o ensino profissionalizante fossem obrigações do Estado para com as classes economicamente menos favorecidas.

Em 1950, a maioria das universidades estaduais foram federalizadas, salvo a USP. E em 1951, foram criados o CNPq, ligado ao Governo Federal, para estimular a pesquisa científica e tecnológica e a CAPES, como Campanha para o Aperfeiçoamento de Pessoal Docente para o Ensino Superior, que depois assume a regulação da pós-graduação brasileira.

Já com a capital do País instalada no Planalto Central, em 1961, foi criada a Fundação da Universidade de Brasília, inspirada no modelo americano de ensino superior. É a primeira a se organizar em departamentos e a dispor de autonomia didática, técnica e administrativa.

No período de 1964 a 1968, as universidades são um dos principais focos de resistência à ditadura militar. A UnB é invadida pela primeira vez e cerca de $85 \%$ dos docentes pedem afastamento dos cargos.

O Presidente Costa e Silva reforma o ensino superior: fim de cátedras, organização institucional em departamentos, desenvolvimento da pós-graduação e pesquisa em escala nacional, enfraquecimento do poder social das universidades o que significou o aumento da burocracia e do limite da autonomia acadêmico-financeira. 
Em 1988, a nova Constituição Federal confere autonomia didático-científica, administrativa e financeira às universidades, mas o princípio não sai do papel devido à burocracia instalada.

Com a aprovação da Lei de Diretrizes e Bases da Educação (1996), novas modalidades de ensino superior são estabelecidas, abrindo espaço para a expansão de instituições de ensino superior privadas. O Censo da Educação Superior de 2003 revela concentração de 70,8\% de matrículas do ensino superior nas instituições privadas e 29,2\% nas públicas.

Em 2004, a reforma universitária volta à pauta política e o MEC convoca a sociedade para debater a proposta. Extingue-se o Provão, cria-se o SINAES e aprova-se a Lei de Incentivo à Inovação e à Pesquisa Científica e Tecnológica, para favorecer a pesquisa no país.

O anteprojeto de lei da reforma universitária (2005) é enviado ao Congresso Nacional e em 2006, o texto vira o Projeto de Lei $n^{0} 7200 / 2006$. O Projeto tem seu foco concentrado em aspectos macro-estruturais de financiamento e de controle institucional, e micro-estruturais de organização e de gestão institucional. Não considera propostas significativas de mudanças no atual modelo de formação acadêmica seja nos níveis de graduação, pós-graduação, seja de quaisquer outras modalidades de educação superior previstas na legislação em vigor.

No ano de 2006, é lançado o projeto Universidade Nova, liderado pelo Reitor da UFBA. A iniciativa é a de repensar a instituição universitária brasileira, com vistas à tarefa de atualizá-la, continuamente, frente aos desafios e exigências dos novos tempos, inspirada na obra de Anísio Teixeira. O movimento Universidade Nova tem rejeição de grupos, mas ganhou adeptos em grande parte do país, cujo principal objetivo é uma reestruturação curricular profunda dos programas de formação universitária.

Ao mesmo tempo, o Governo Federal lança o Programa de Apoio a Planos de Reestruturação e Expansão das Universidades Federais - REUNI, instituído pelo Decreto n. 6.096, de 24 de abril de 2007, com o objetivo de criar condições para a ampliação do acesso e a permanência na educação superior, no nível de graduação, pelo melhor aproveitamento da estrutura física e de recursos existentes nas universidades federais. 
A exemplo do projeto Universidade Nova, o programa também encontra resistência. O Andes - Sindicato Nacional dos Docentes das Instituições de Ensino Superior considera o objetivo traçado no Decreto incompatível com a qualidade da Educação Superior, dada a precariedade das condições em que se encontram as IFES, em termos de infra-estrutura e de insuficiência do quadro docente e técnico-administrativo. Para o Andes "a implementação deste processo resultará numa universidade desfigurada, descaracterizada, transformada em escola de $3^{\circ}$ grau, subtraída de suas funções sociais de produção e socialização do conhecimento científico, tecnológico e cultural”.

\subsection{O Financiamento da Educação Superior no Brasil}

A Educação Superior no período militar foi priorizada mesmo com a redução dos gastos com a educação em geral, imposta pelo governo. As universidades federais tiveram considerável ampliação de despesas, sem mecanismos de prestação de contas ou avaliação, o que inviabilizou investimentos em capital e na melhoria da qualidade.

Nas décadas de 70 e 80, o governo destacou volumosos recursos às universidades, permitindo expandir a pesquisa científica, a instituição da pós-graduação stricto sensu articulada à carreira docente e a multiplicação dos centros de formação. O controle era exercido severamente pelo MEC, limitando as possibilidades de diversificação e ajustamento das modalidades de gasto às necessidades de cada instituição.

A Emenda João Calmon, promulgada em 1983 e regulamentada em 1985, restabeleceu a vinculação de recursos para aplicação na manutenção e no desenvolvimento do ensino de pelo menos $13 \%$ de sua receita de impostos e, aos estados, ao Distrito Federal e aos municípios, o mínimo de $25 \%$.

O sistema de financiamento da educação pública no Brasil desde autoritarismo, vinha sendo reestruturado com o aumento e a garantia do financiamento público. Apesar do fim do regime militar, não foram promovidas mudanças substanciais no sistema educacional do país.

A Constituição de 1988 introduziu a Emenda João Calmon, alterando o percentual para $18 \%$ das receitas de impostos. Além disso, os docentes e técnico-administrativos foram incluídos no regime estatutário garantindo-lhes sindicalização. 
O governo de 1990 (Fernando Collor), no entanto, enfrentou vários problemas de falta de diretrizes, debilidade dos instrumentos legais de controle e constantes conflitos corporativos e institucionais. O Plano Plurianual 1991-1995 priorizou a reestruturação dos gastos com vistas a assegurar o equilíbrio das contas públicas. As instituições federais de ensino superior foram estimuladas a buscar recursos de outras fontes, públicas e privadas, no intuito de ampliar o atendimento a outras demandas sociais que não o ensino.

Os anos de 1995 a 2002 foram marcados pela integração do país à economia mundial, o que deu ênfase ao novo papel atribuído ao mercado na alocação dos recursos e diminuiu as funções do Estado, em especial como provedor dos serviços sociais, entre eles, a educação. As medidas recomendadas foram: combate ao deficit público, ajuste fiscal, privatização, liberação/ajuste de preços, desregulamentação do setor financeiro, liberação do comércio, incentivo aos investimentos externos, reforma do sistema de previdência/seguridade social e reforma, desregulamentação e flexibilização das relações de trabalho.

No período 1994-2002, o ensino superior público federal teve uma expansão de $37 \%$ nas matrículas e uma redução de $5 \%$ no seu corpo docente e de $21 \%$ no seu quadro de funcionários, além do quase congelamento salarial de docentes e funcionários técnicoadministrativos.

Durante o governo de Fernando Henrique Cardoso, o MEC tentou aprovar, no Congresso Nacional, emendas constitucionais ou leis ordinárias que promovessem a autonomia das IFES, inclusive autorizando-as a arrecadarem fundos de qualquer natureza, na ausência do financiamento estatal (constitucional). Além disso, incentivou-se a criação das criticadas Fundações de Apoio Institucional.

No governo atual, algumas iniciativas foram implementadas na área de educação, conforme descrito no item anterior, sendo a mais significativa o Programa de Apoio a Planos de Reestruturação e Expansão das Universidades Federais.

Os recursos de investimento e custeio previstos para o REUNI, considerando a participação de todas as universidades federais, foram projetados para o período de 2008 a 2011 e são da ordem de 2 bilhões de reais (v. tabela abaixo). O valor acrescido ao orçamento de custeio e pessoal de cada universidade aumentará gradativamente, no período de cinco anos, até atingir, ao final, o montante correspondente a $20 \%$ do previsto para 2007. A 
liberação dos recursos está condicionada à aprovação do plano e assinatura de termo de pactuação de metas correspondente.

Tabela 1 - Previsão de acréscimo orçamentário a partir do Decreto n 6.096/2007 (valores em milhares de reais)

\begin{tabular}{|l|c|c|c|c|c|c|}
\hline Ano & $\mathbf{2 0 0 8}$ & \multicolumn{2}{|c|}{$\mathbf{2 0 0 9}$} & \multicolumn{2}{c|}{$\mathbf{2 0 1 0}$} & \multicolumn{2}{|c|}{$\mathbf{2 0 1 1}$} & $\mathbf{2 0 1 2}$ \\
\hline Investimento & 305.843 & \multicolumn{2}{|c|}{567.671} & \multicolumn{2}{|c|}{593.231} & \multicolumn{2}{c|}{603.232} \\
\hline Custeio/Pessoal & 174.157 & 564.247 & 975.707 & 1.445 .707 & 1.970 .205 \\
\hline Total & $\mathbf{4 8 0 . 0 0 0}$ & $\mathbf{1 . 1 3 1 . 9 1 8}$ & $\mathbf{1 . 5 6 8 . 9 3 8}$ & $\mathbf{2 . 0 4 8 . 9 3 9}$ & $\mathbf{1 . 9 7 0 . 2 0 5}$ \\
\hline
\end{tabular}

Fonte: Decreto n ${ }^{\circ}$ 6.096/2007 


\section{A HISTÓRIA DA FUNDAÇÃO UNIVERSIDADE DE BRASÍLIA}

A Fundação Universidade de Brasília (FUB) foi criada em 1961, pela Lei $\mathrm{n}^{\circ}$ 3.998 de 15/12/61, para manter a Universidade de Brasília (UnB), primeira instituição de ensino superior de pesquisa e estudo estabelecida no Distrito Federal. A Fundação foi dotada de patrimônio próprio, cuja exploração garantiria a instalação e o financiamento das atividades desenvolvidas pela Universidade.

A estrutura e o regimento da Fundação foram aprovados por Decreto do Poder Executivo e neles definidos os objetivos, a forma de organização e a estrutura da FUB; o patrimônio; o regime financeiro; o sistema de prestação de contas; a forma de contratação de pessoal; a estrutura geral da Universidade integrada entre Institutos, Faculdades e Órgãos Complementares e a organização da carreira docente.

O Plano Orientador da Universidade de Brasília (UnB, 1962) previa a criação de oito Institutos Centrais; seis Faculdades (ligadas a quatorze Centros de Pesquisa, às Casas Nacionais da Língua e da Cultura, ao Museu de Arte e ao Hospital Escola); dez Órgãos Complementares (Aula Magna, Biblioteca Central, a Rádio UnB, a Televisão UnB, a Editora, o Museu, as Casas da Cultura, o Centro Educacional unidade de demonstração da Faculdade de Educação, o Centro Recreativo e Cultural e o Estádio Universitário).

As previsões do Plano de Implantação da UnB não foram totalmente concretizadas. As mudanças políticas ocorridas no País na década de sessenta refletiram-se na Universidade e levaram à redução do número de unidades acadêmicas de 16 para 9. Além disso, apenas dois dos órgãos complementares foram instalados inicialmente: a Biblioteca Central (BCE) e a Editora Universidade de Brasília (EDU), os quais foram seguidos do Centro de Processamento de Dados (CPD).

Em 1985, após a mudança na gestão universitária, a UnB passou por uma primeira grande reestruturação. Essa reorganização teve por objetivo declarado estimular o desenvolvimento das atividades acadêmicas e aproximar a Administração Superior da vida comunitária, inclusive com a aprovação de um Regimento da Administração Superior. 
Após as mudanças ocorridas em 1985, poucos ajustes estruturais foram feitos: a criação ou desmembramento de unidades ou a implementação de mudanças localizadas em processos administrativos.

Em 1993 o Estatuto da Universidade foi revisto com a finalidade de simplificar a gestão universitária e dar maior transparência aos atos dos gestores. Em abril de 2001 o novo Regimento Geral da UnB foi publicado no Diário Oficial da União. Nele foi estabelecido o prazo de seis meses para que se procedesse à revisão dos Regimentos Internos das Unidades Acadêmicas, dos Órgãos Complementares e dos Centros existentes.

No ano seguinte, por ocasião da implantação do Sistema de Planejamento Institucional, os gestores identificaram que $10 \%$ do total dos pontos fracos da Universidade estavam relacionados à reestruturação organizacional e a alterações regimentais. É relevante considerar que, naquele ano, os problemas decorrentes da inadequação das estruturas e das deficiências de rotinas e processos foram considerados mais relevantes pelos gestores de Centros e de Unidades Administrativas.

Apesar da importância atribuída à questão pela comunidade universitária, não foi possível, nos anos seguintes, implementar as mudanças propostas. Na versão preliminar do Diagnóstico Institucional, do qual participaram 47 das 60 unidades que integram o Sistema de Planejamento, já foi possível avaliar que a questão organizacional assumiu papel ainda mais relevante. Assim, os gestores identificaram que $20 \%$ dos pontos fracos que mais comprometem o desenvolvimento institucional estão associados a deficiências de processos e estruturas. Vale destacar, ainda, que tão significativo quanto o elevado percentual é a importância atribuída ao tema pelas Unidades Acadêmicas e Centros.

\subsection{Pontos Fortes e Fracos apontados pelos Gestores}

O Diagnóstico Institucional da Universidade feito por gestores das unidades integrantes do Sistema de Planejamento Institucional, ocorrido em 2006, para estabelecer o Plano de Desenvolvimento Institucional 2007-2010, identificou os aspectos internos mais relevantes da gestão universitária que pudessem contribuir ou comprometer o processo de desenvolvimento organizacional.

A totalidade dos gestores identifica como aspectos estruturais mais relevantes, a vinculação imediata ao Gabinete do Reitor e o interesse da administração em promover a 
integração entre unidades. Os gestores de unidades administrativas e prestadoras de serviços internos revelaram outros pontos considerados positivos: a modernização de processos e as vantagens decorrentes da gestão colegiada.

Os pontos fracos destacados, segundo os gestores, foram: a falta de formalização de processos e políticas; a proliferação de núcleos temáticos; a estrutura organizacional inadequada; a falta de articulação interna e externa entre as unidades; a burocracia excessiva no tocante ao andamento dos processos; o não cumprimento de prazos regimentais e legais pela comunidade e pelos gestores e a deficiência no gerenciamento da captação de recursos.

Após a elaboração do Diagnóstico Institucional, os gestores apresentaram sugestões de prioridades a serem adotadas pela Administração da Universidade, para o período 2007 a 2010. Em relação à organização da Universidade e seus processos, indicaram as seguintes propostas de prioridade (UnB, 2007):

· modernização da gestão e dos processos;

· institucionalização, reestruturação e integração de unidades;

- definição e atualização de normas e criação de estruturas específicas.

\subsection{A FUB e o CESPE/UnB}

A Fundação Universidade de Brasília - FUB, como já dito, é uma fundação instituída pela Lei $\mathrm{n}^{\circ} 3.998$, de 15 de novembro de 1961 e pelo Decreto $\mathrm{n}^{\circ} 500$, de 15 de janeiro de 1962, criada pelo poder público e constituída por patrimônio destacado da União. A FUB tornou-se fundação pública por meio da Lei $n^{0}$ 7596/87 e é mantida pela destinação orçamentária regular de recursos federais de custeio, manutenção, remuneração de pessoal bem como de proventos de inativos. Trata-se, portanto, de fundação pública instituída e mantida pelo poder público federal.

As atividades realizadas pela FUB integram o âmbito dos serviços "vinculados a suas finalidades essenciais ou às delas decorrentes", conforme se observa no artigo 10 de sua lei de criação:

Art. 10. A Universidade de Brasília empenhar-se-á no estudo dos problemas relacionados com o desenvolvimento econômico, social e cultural do País e, na medida de sua possibilidade, na colaboração às entidades públicas e privadas que o solicitarem. (BRASIL, 1961, p.1) 
No mesmo diapasão, vê-se no art. 29 (“A Universidade empenhar-se-á no estudo dos problemas relacionados com o desenvolvimento econômico, social e cultural do País, colaborando com as entidades públicas e privadas para tal objetivo") do Estatuto da FUB, baixado com o Decreto $n^{\text {o }}$ 500/62 que a FUB possuía a destinação legal e estatutária à prestação de serviço à comunidade como elemento nuclear e definidor de suas finalidades essenciais, desde a sua criação.

As universidades, de maneira geral, possuem suas finalidades essenciais previstas, de modo expresso na Constituição. O art. 207 do texto constitucional impõe às universidades, imediatamente após assegurar a sua autonomia didático-científica, administrativa e de gestão financeira e patrimonial, o dever de observância ao princípio da indissociabilidade entre ensino, pesquisa e extensão. Assim, as universidades encontram-se sujeitas à realização, de modo indissociável, do ensino, da pesquisa e da extensão. Conclui-se, pois, serem essas três atividades suas finalidades essenciais.

A FUB, cujo objetivo é criar e manter a Universidade de Brasília, encontra-se constitucionalmente vinculada, portanto, à criação, à realização, à manutenção e ao desenvolvimento das atividades de ensino, pesquisa e extensão.

O conceito das atividades essenciais das Universidades foi tratado no Parecer SR78, da Consultoria-Geral da República, de 15 de dezembro de 1988, publicado no DO de 16/12/88, Seção I, p. 24582-24585, com caráter normativo para a Administração Pública Federal. O parecer, como já mencionado, conceitua as finalidades essenciais das universidades como "sua tríplice destinação: o ensino (transmissão de conhecimentos), a pesquisa (produção de novos conhecimentos) e a extensão (prestação de serviços à comunidade)" (DO de 16/12/88, Seção I, p. 24584).

Cabe, em nosso ordenamento constitucional, exclusivamente ao Supremo Tribunal Federal, a fixação da interpretação definitiva da Constituição Federal.

Acrescente-se, que o Supremo Tribunal Federal (STF) fixou interpretação definitiva sobre as "finalidades essenciais" das universidades, de modo em tudo consonante ao Parecer referido, na Ação Direta de Inconstitucionalidade $\mathrm{n}^{\circ}$ 51-RJ. O STF reiterou o entendimento exposto no Parecer da Consultoria-Geral da República reconhecendo as universidades com "sua tríplice destinação: o ensino (transmissão de conhecimentos), a pesquisa (produção de novos conhecimentos) e a extensão (prestação de serviços à comunidade)" (Revista Trimestral de Jurisprudência $n^{\circ}$ 148, p. 12). Com isso, conclui-se que 
as atividades de prestação de serviço à comunidade constituem, inequivocamente, o conceito de extensão, definida como finalidade essencial das universidades pelo art. 207 do texto constitucional.

A título de enriquecimento acadêmico, é relevante salientar o conceito de extensão universitária defendido pelo Prof. Oberdan Dias da Silva em sua palestra proferida no II Simpósio Multidisciplinar "A Integração Universidade-Comunidade", em 10 de outubro de 1996:

Extensão universitária. é, na realidade, uma forma de interação que deve existir entre a universidade e a comunidade na qual está inserida. É uma espécie de ponte permanente entre a universidade e os diversos setores da sociedade. Funciona como uma via de duas mãos, em que a Universidade leva conhecimentos e/ou assistência à comunidade, e recebe dela influxos positivos como retroalimentação tais como suas reais necessidades, seus anseios, aspirações e também aprendendo com o saber dessas comunidades. Ocorre, na realidade, uma troca de conhecimentos, em que a universidade também aprende com a própria comunidade sobre os valores e a cultura dessa comunidade. Assim, a universidade pode planejar e executar as atividades de extensão respeitando e não violando esses valores e cultura. A universidade, através da Extensão, influencia e também é influenciada pela comunidade, ou seja, possibilita uma troca de valores entre a universidade e o meio (SILVA, 1996).

A prestação de serviço à comunidade confunde-se, no âmbito da universidade, com o conceito de extensão, finalidade essencial da FUB. Os doutrinadores brasileiros e estrangeiros buscam identificar as finalidades essenciais de qualquer entidade em seus atos constitutivos bem como em suas disposições estatutárias e regimentais. Vê-se, pois, que a conceituação jurídica das finalidades essenciais da FUB já constava originariamente de texto expresso de lei desde a sua criação.

Dentro das finalidades essenciais da Universidade, o CESPE/UnB aparece na estrutura da Universidade (Figura 1) como órgão prestador de serviços, com autonomia administrativa, que, além de seus objetivos de planejamento e execução de vestibulares e outros processos de acesso, presta diversos serviços à sociedade, em especial os relacionados à organização e à realização de concursos públicos, processos seletivos, eventos, cursos variados, certificações e avaliações educacionais. Atualmente é o maior captador de recursos da instituição, reconhecido nacionalmente. 


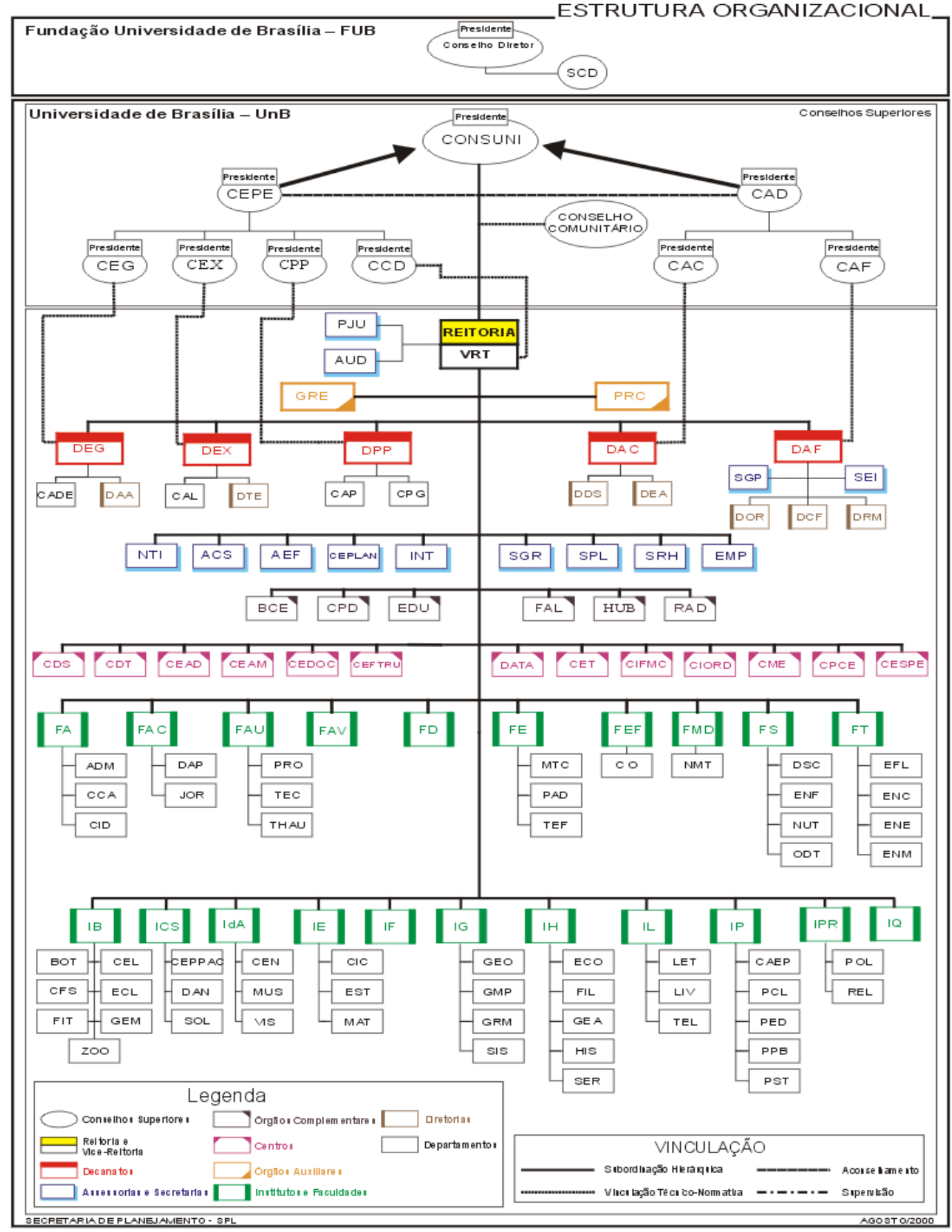

Figura 1 - Organograma da FUB 


\subsection{A história do Centro de Seleção e de Promoção de Eventos (CESPE/UnB)}

Nos termos do art. 42 do Estatuto da UnB e do art. 42 do Regimento Geral da UnB, o Centro de Seleção e de Promoção de Eventos (CESPE/UnB) da Universidade de Brasília (UnB), foi constituído em 1993 pelo Ato da Reitoria n.o 1.777/93, vinculado ao Gabinete do Reitor, para executar os processos de seleção de estudantes para o ingresso na Universidade e realizar os concursos públicos, processos seletivos e avaliações educacionais.

A história do CESPE/UnB confunde-se com a história dos vestibulares na Universidade de Brasília.

Ao longo do tempo, o vestibular foi muito aperfeiçoado: as vagas foram ampliadas, as inscrições foram informatizadas e são feitas também pela internet, e a qualidade pedagógica e gráfica dos exames é constantemente elogiada por professores e candidatos.

Também foram implantadas inovações como: o fornecimento do Boletim de Desempenho das Escolas; a Sala dos Professores, em que professores do ensino médio fazem a prova simultaneamente com os alunos, em um ambiente isolado e seguro, o que gera uma proposta de gabarito, considerada e discutida pelas bancas examinadoras, e as suas críticas e sugestões são passadas para a equipe acadêmica do CESPE/UnB; a mudança de horário das provas para o período vespertino, resultante em maior conforto aos candidatos; a publicação do Jornal do Vestibular, com informações aos candidatos; a renovação do projeto gráfico do Guia do Vestibulando, acompanhada de melhor nível de informação; a descentralização de inscrições e da aplicação das provas; a informatização de inscrições, por meio de formulários de leitura óptica e pela Internet. Desde o segundo semestre de 2004, o vestibular da UnB também vem adotando a aplicação de cotas de vagas para negros.

Todas as etapas do processo seletivo têm sido feitas por meio eletrônico, o que praticamente eliminou a possibilidade de erros. É consensual, ao mesmo tempo, o compromisso do CESPE/UnB com a idoneidade de seus vestibulares. Por isso, nenhum vestibular foi, até hoje, anulado ou suspenso.

Desde 1996, a Universidade de Brasília, por intermédio do CESPE/UnB, utiliza uma modalidade alternativa para o ingresso em cursos de graduação. Trata-se do Programa de Avaliação Seriada (PAS), que tem os seguintes objetivos: implantar um processo seletivo para os cursos de graduação da UnB, alicerçado na integração da educação básica com a superior, visando à melhoria da qualidade do ensino em todos os níveis, com base no princípio de que a vida escolar deve-se caracterizar como um continuum; selecionar os futuros estudantes 
universitários, de modo gradual e sistemático, não como o produto de um único exame seletivo episódico, mas como a culminância de um processo desenvolvido ao longo do ensino médio; definir os parâmetros de um processo seletivo que busque a avaliação da aprendizagem significativa, em que se privilegiem a reflexão sobre a memorização, a qualidade sobre a quantidade de informações, o ensino sobre o adestramento e o processo sobre o produto; adotar, como eixos estruturadores da avaliação, a contextualização e a interdisciplinaridade, com ênfase no desenvolvimento de competências e habilidades.

As características do PAS exigem planejamento e execução diferenciados e complexos, com inscrições e aplicação de provas nas escolas dos candidatos, em três oportunidades anuais, correspondentes às etapas que se realizam ao longo das séries do ensino médio. Apesar de recente, esse programa evidencia resultados positivos, tanto sociais quanto pedagogicamente, e constitui importante mecanismo de avaliação de alunos e de instituições de ensino médio. Todas as escolas cadastradas no PAS recebem uma análise estatística de desempenho de seus alunos, o que possibilita o desenvolvimento de ações pedagógicas de melhoria da qualidade do ensino oferecido por elas.

As equipes que atuam em vestibulares, em concursos e em outros eventos de avaliação da aprendizagem têm altos níveis de qualificação formal, integram os corpos docente e técnico-administrativo e, em virtude da intensa atividade do CESPE/UnB nos últimos anos, vêm atingindo elevados patamares qualitativos de desempenho, aliados à sólida reputação de honestidade e confiança demonstradas ao longo de vários anos.

Desde o ano 2000, o CESPE/UnB se envolveu mais intensamente com a área de avaliação de sistemas educacionais, ao constituir, formalmente, a gerência de Pesquisa em Avaliação, hoje Coordenadoria de Pesquisa em Avaliação, centralizando nessa instância os trabalhos que vinham sendo desenvolvidos na área de avaliação educacional. Atualmente, a coordenadoria conta com um laboratório de medidas educacionais e com um grupo de especialistas (psicometristas, estatísticos, pedagogos, matemáticos e lingüistas) atuando na análise de desempenho de alunos em processos de avaliação de sistemas educacionais e na análise de desempenho de candidatos em concurso públicos, processos seletivos e vestibulares.

Em 2005, o CESPE/UnB teve sua estrutura organizacional reestruturada mediante o Ato da Reitoria n ${ }^{\circ}$ 1.654/2005, configurando-se conforme apresentado na Figura 2 a seguir. 
Aprova a estrutura organizacional do Centro de Seleção e de Promoção de Eventos da Universidade de Brasília.

O PRESIDENTE DA FUNDAÇÃO E REITOR DA UNIVERSIDADE DE BRASÍLIA, no uso das suas atribuições estatutárias e de acordo com o disposto no art. 25 do Estatuto da Universidade de Brasília, aprovado pela Portaria do MEC n. 14, de 5 de janeiro de 1994, e considerando:

I. o disposto na Resolução da Reitoria n. 60, de 18 de novembro de 2005;

II. as finalidades essenciais das Instituições de Educação Superior: o ensino (transmissão de conhecimentos), a pesquisa (produção de novos conhecimentos) e a extensão (prestação de serviços à comunidade);

III. a necessidade de atualização da estrutura e dos procedimentos administrativos do CESPE/Centro de Seleção e de Promoção de Eventos órgão da Universidade de Brasília, com autonomia administrativa delegada por meio do Ato da Reitoria n. 601, de 24 de abril de 2002, que, além de seus objetivos acadêmicos de planejamento e execução dos vestibulares e do Programa de Avaliação Seriada, presta diversos serviços à comunidade externa, em especial os relacionados à organização e à realização de concursos públicos, processos seletivos, avaliações educacionais e institucionais, pesquisas em geral, certificação e acreditação, eventos e cursos variados voltados à educação corporativa,

\section{R E S O L V E:}

Art. 1 ${ }^{-} \quad$ Aprovar a estrutura organizacional do Centro de Seleção e de Promoção de Eventos da UnB, na forma do anexo a este Ato.

Art. $2^{-} \quad$ Este Ato e seu anexo entram em vigor nesta data, revogadas as disposições em contrário, em especial o Ato da Reitoria n. 1.129, de 20 de agosto de 1996.

Brasília, 30 de dezembro de 2005.

Timothy Martin Mulholland

Reitor

C/ cópia: VRT, Decanos, todos os Centros de Custo.

CESPE/esp.

ANEXO ao Ato da Reitoria n. 1.654, de 30 de dezembro de 2005.

Estrutura Organizacional do Centro de Seleção e de Promoção de Eventos

\section{CAPÍTULO I}

Da Organização Geral

Art. 1ํㅗ A estrutura organizacional do Centro de Seleção e de Promoção de Eventos, órgão da Universidade de Brasília vinculado ao Gabinete do Reitor, compreende:

I. Conselho Técnico-Consultivo;

II. Diretoria-Geral:

a) Assessoria Técnica;

b) Secretaria Administrativa;

c) Ouvidoria.

III. Diretoria-Executiva: 
a) Centros Regionais;

b) Comitê Executor;

c) Comitê de Ética e Disciplina.

IV. Central de Atendimento;

V. Coordenadoria de Planejamento e Gestão:

a) Gerência de Operações Contábeis e Financeiras;

b) Gerência de Recursos Materiais e Patrimoniais;

c) Gerência de Recursos Humanos;

d) Gerência de Infra-estrutura e Manutenção.

VI. Coordenadoria Acadêmica:

a) Gerência de Acesso à Educação Superior;

b) Gerência de Concursos Públicos;

c) Gerência de Diagramação e Impressão.

VII. Coordenadoria de Negócios:

a) Gerência de Atendimento a Clientes Institucionais;

b) Gerência de Contratos e Propostas;

c) Gerência de Educação Corporativa.

VIII. Coordenadoria de Tecnologia:

a) Gerência de Controle e Conferência;

b) Gerência de Administração de Redes e Banco de Dados;

c) Gerência de Produção Digital;

d) Gerência de Desenvolvimento e Produção.

IX. Coordenadoria de Logística de Eventos:

a) Gerência de Espaço Físico e Transportes;

b) Gerência de Distribuição de Pessoal;

c) Gerência de Organização de Material.

X. Coordenadoria de Pesquisa em Avaliação:

a) Gerência de Interação Educacional;

b) Gerência de Análise de Dados;

c) Gerência de Produção de Relatórios.

\section{CAPÍTULO II}

Da Categoria e Competências

Art. 2ำ Ao CESPE compete:

I. planejar e executar os concursos vestibulares e o Programa de Avaliação Seriada/PAS da Universidade de Brasília;

II. prestar serviços à FUB/UnB e à comunidade externa, em especial:

a) organizar e realizar concursos públicos e processos seletivos, por meio de processos e métodos científicos, assim como prestar assessoramento e consultoria nesse campo; 
b) proceder a avaliações educacionais e institucionais que permitam retratar as tendências; formular objetivos; apontar acertos e fracassos e identificar o que é relevante, prioritário e coerente com os objetivos formulados;

c) realizar pesquisas no campo das ciências econômicas e do comportamento, com especial ênfase as de interesse educacional e mercadológicas;

d) certificar e proceder à acreditação de entidades e instituições, cursos e habilidades nas diversas áreas do conhecimento, em conformidade com padrões científicos mundialmente aceitos e estabelecidos;

e) dar suporte a eventos em todos os níveis, como por exemplo reuniões, simpósios, congressos e seminários;

f) realizar cursos variados voltados à educação corporativa.

Art. 3ำ O CESPE, observadas as suas finalidades, poderá formalizar termos de acordos, convênios, ajustes e contratos para a prestação de serviços, além de outros instrumentos similares, com instituições públicas e privadas.

\section{CAPÍTULO III}

Das Competências

Art. $4^{\underline{0}}$ Ao Conselho Técnico-Consultivo compete prestar orientação, aconselhamento e recomendações à Direção do CESPE, o que pode ser feito de forma expressa ou verbal.

$\S 1^{\circ}$ O Conselho Técnico-Consultivo é constituído de três a cinco membros, nomeados pelo Reitor, com mandato de dois anos, que tenham formação e/ou experiência em pelo menos uma das seguintes áreas: gestão, economia, finanças, informática, desenvolvimento, pesquisa, recursos humanos, entre outras que tenham correlação com os objetivos finalísticos do CESPE.

$\S 2^{\circ}$ O Conselho Técnico-Consultivo se reunirá ordinária e extraordinariamente.

$\S 3^{\circ}$ As consultas ao Conselho Técnico-Consultivo independem da realização de reunião ordinária, podendo seus posicionamentos serem formalizados por meio de documento do Colegiado, devidamente assinado pelos seus componentes, ou em Ata da reunião, quando for o caso.

$\S 4^{\text {o }}$ O Conselho Técnico-Consultivo poderá contratar consultores externos e técnicos especializados, quando necessário.

Art. 5ํํ Diretoria-Geral compete:

I. dirigir, coordenar, controlar e avaliar as atividades relativas aos concursos vestibulares e ao Programa de Avaliação Seriada, em conformidade com as diretrizes estabelecidas pelo Decanato de Ensino de Graduação;

II. dirigir, coordenar, controlar e avaliar as atividades relativas aos concursos públicos realizados para a FUB e para órgãos externos;

III. decidir acerca do apoio e da realização de eventos diversos para a FUB e para órgãos externos;

IV. decidir acerca da prestação de serviços do CESPE a órgãos municipais, estaduais e federais, relativa a consultorias, cursos de formação, entre outros compatíveis com as atribuições do Centro;

V. encaminhar, para assinatura do Reitor, os termos de acordos, convênios, ajustes e contratos de prestação de serviços e outros instrumentos similares;

VI. acompanhar a execução de todos os acordos, convênios, ajustes e contratos de prestação de serviços e instrumentos similares.

Art. $6^{\circ}$ À Diretoria-Executiva compete:

I. prestar assessoramento técnico à Diretoria-Geral; 
II. dirigir, coordenar, controlar e avaliar as atividades relativas ao detalhamento de receitas e de despesas necessárias à realização de concursos e demais eventos;

III. planejar, coordenar, controlar e avaliar as atividades relacionadas à gestão dos recursos recebidos para a execução dos convênios e instrumentos similares;

IV. gerar, tratar e disseminar as informações de cunho administrativo no âmbito do CESPE.

Art. $7^{\circ}$ À Central de Atendimento compete:

I. atender ao público em geral, auxiliando e orientando quanto aos eventos, processos seletivos, consultorias e concursos realizados pelo CESPE;

II. atender, de forma diferenciada, os candidatos portadores de necessidades especiais, com vistas a proporcionar-lhes as condições necessárias à participação nos processos seletivos e de avaliação;

III. receber e autuar os recursos interpostos por candidatos nos processos executados pelo CESPE.

Art. $8^{\mathrm{o}}$ À Coordenadoria de Planejamento e Gestão compete:

I. prestar assessoramento técnico à Diretoria-Executiva;

II. coordenar, planejar e avaliar as atividades administrativas do CESPE;

III. coordenar, planejar, controlar, manter e avaliar as atividades relacionadas à gestão dos recursos humanos, materiais e patrimoniais, assim como os serviços de infra-estrutura e manutenção;

IV. coordenar e controlar as operações contábeis e financeiras e informar à Previdência Social e à Receita Federal os dados relacionados aos fatos geradores de contribuição previdenciária e de tributos federais.

Art. $9^{\circ}$ À Coordenadoria Acadêmica compete:

I. prestar assessoramento técnico à Diretoria-Geral;

II. coordenar, planejar e executar as atividades acadêmicas que permeiam os eventos realizados;

III. estabelecer critérios de seleção e definir objetos de avaliação adequados aos processos organizados;

IV. selecionar profissionais especializados e capacitá-los para comporem bancas elaboradoras e/ou avaliadoras dos eventos executados pelo CESPE;

V. revisar e adequar os instrumentos de avaliação a serem utilizados nos processos promovidos;

VI. realizar a diagramação, a arte final, a reprodução e o empacotamento dos materiais sigilosos de avaliação;

VII. adaptar os instrumentos de avaliação para os portadores de necessidades especiais;

VIII. confeccionar os gabaritos das provas objetivas e as planilhas de avaliação das provas discursivas e orais;

IX. proceder à avaliação de recursos interpostos pelos candidatos contra os instrumentos de avaliação aplicados;

X. zelar pelo sigilo da informação inerente aos processos de responsabilidade da Coordenadoria.

Art. 10. À Coordenadoria de Negócios compete:

I. prestar assessoramento técnico à Diretoria-Geral e à Executiva;

II. coordenar, planejar, elaborar e atualizar a agenda de compromissos do CESPE; 
III. coordenar, planejar, elaborar, revisar, montar, acompanhar e encaminhar aos clientes as propostas de prestação de serviços, contratos e cronogramas para a execução dos processos/concursos;

IV. manter porta-fólio atualizado do CESPE, com pareceres, estatutos, estrutura organizacional, certidões negativas, minutas de contratos e atestados de capacidade técnica;

V. elaborar os editais de processos/concursos, na forma da lei, e as demais informações pertinentes;

VI. articular-se com organizações públicas e privadas executoras de programas de educação corporativa, identificando oportunidades de desenvolvimento de RH;

VII. criar e desenvolver linha de pesquisa na geração de produtos, processos e serviços associados à formação e ao desenvolvimento de RH.

Art. 11. À Coordenadoria de Tecnologia compete:

I. prestar assessoramento técnico à Diretoria-Geral e à Executiva;

II. coordenar e planejar as atividades de informática necessárias;

III. processar eletronicamente vestibulares, PAS, concursos e eventos;

IV. desenvolver sistemas de correção de provas objetivas, discursivas e práticas, gerando os respectivos relatórios de resultados e assemelhados;

V. apoiar as diversas áreas do CESPE em matérias relacionadas à tecnologia da informação, inclusive desenvolvendo sistemas próprios;

VI. buscar, pesquisar e implementar constantemente a inovação tecnológica, preocupando-se sempre com os aspectos de segurança da informação;

VII. zelar pelo sigilo da informação inerente aos processos de responsabilidade da Coordenadoria.

Art. 12. À Coordenadoria de Logística de Eventos compete:

I. prestar assessoramento técnico à Diretoria-Geral e à Executiva;

II. coordenar, planejar, definir, conferir, organizar e montar os materiais necessários aos procedimentos de inscrição, matrículas, coordenação e aplicação dos concursos/processos;

III. controlar a utilização dos materiais e equipamentos referentes à aplicação dos concursos/processos;

IV. gerir a reprografia externa do CESPE no tocante à reprodução de materiais não-sigilosos, para aplicação de concursos/processos;

V. reservar e contratar espaço físico adequado para aplicação de provas e realização de eventos em âmbito nacional;

VI. reservar e contratar hospedagem em hotéis, locação de veículos e aeronaves necessários para o cumprimento das obrigações contratadas;

VII. responsabilizar-se pelo envio e recebimento de cargas e pela autorização de emissão de bilhetes de passagens aéreas;

VIII. manter cadastro atualizado de pessoal qualificado para exercer funções inerentes ao processo de eventos executados pelo CESPE.

Art. 13. À Coordenadoria de Pesquisa em Avaliação compete:

I. prestar assessoramento técnico à Diretoria-Geral;

II. coordenar, elaborar, avaliar e executar pesquisas voltadas para o aperfeiçoamento dos mecanismos de acesso ao ensino superior e de métodos para elaboração de instrumentos de avaliação; 
III. promover avaliações educacionais e institucionais que permitam retratar as tendências; formular objetivos; apontar acertos e fracassos; identificar o que é relevante, prioritário e coerente com os objetivos a que visar;

IV. promover ações concernentes com os resultados das avaliações educacionais e institucionais;

V. promover certificação e acreditação de entidades e instituições, cursos e habilidades, nas diversas áreas do conhecimento, em conformidade com padrões científicos mundialmente aceitos e estabelecidos;

VI. promover a realização de pesquisas no campo das ciências econômicas e do comportamento, com especial ênfase às de interesse educacional e mercadológicas;

VII. atuar como elemento de interação entre a educação básica e o ensino superior, por meio de atividades, instâncias, projetos e instrumentos atinentes à natureza dos processos envolvidos.

Art. 14. À Assessoria Técnica compete:

I. prestar assessoramento à Diretoria-Geral e à Executiva em assuntos de natureza diversa;

II. responsabilizar-se pela divulgação das atividades desenvolvidas e coordenar a produção de materiais informativos e o fluxo de comunicação com as comunidades interna e externa;

III. atender à imprensa, sempre que solicitada;

IV. formalizar, emitir parecer e encaminhar processos que envolvam matérias relativas às prestações de serviços realizadas;

V. controlar a entrada e a saída de ações judiciais no âmbito do CESPE e seus contratantes, mantendo permanente controle dessas ações;

VI. prestar informações técnicas à Procuradoria Jurídica da FUB/UnB e aos contratantes do CESPE;

VII. elaborar relatórios técnicos;

VIII. acompanhar trabalhos de auditorias interna e externa;

IX. orientar a Direção do Centro sobre os controles e as normas internas e a legislação federal às quais o CESPE está sujeito;

X. manter, planejar e definir o plano de segurança de eventos e concursos;

XI. transmitir e orientar acerca das medidas de segurança necessárias às atividades desenvolvidas.

Art. 15. À Secretaria Administrativa compete:

I. receber e controlar o recebimento e a expedição de documentos, processos e correspondências;

II. atender ao público em geral;

III. preparar remessa de correspondências;

IV. disseminar documentos ou arquivá-los, quando for o caso;

V. coordenar e controlar as tarefas desempenhadas pelos colaboradores da recepção, da copa e da limpeza e pelos motoristas;

VI. proceder à disseminação, à atualização e à manutenção dos documentos do CESPE;

VII. elaborar e manter atualizadas as estatísticas afetas à Secretaria.

Art. 16. Ao Comitê de Ética e Disciplina, observado o que dispõe o Capítulo II do Decreto n. 1.171, de 22 de junho de 1994, compete: 
I. orientar e aconselhar os agentes do CESPE sobre a ética profissional do servidor, no tratamento com as pessoas e com o patrimônio público, competindo-lhe conhecer concretamente de imputação ou de procedimento susceptível de censura;

II. instaurar, de ofício, processo sobre ato, fato ou conduta que considerar passível de infringência a princípio ou norma ético-profissional, podendo ainda conhecer de consultas, denúncias ou representações formuladas contra o agente ou servidor público, a Coordenadoria ou unidade em que haja ocorrido a falta, cuja análise e deliberação forem recomendáveis para atender ou resguardar o exercício da atividade, do cargo ou função pública, desde que formuladas por autoridade, servidor, jurisdicionados administrativos, qualquer cidadão que se identifique ou quaisquer entidades associativas regularmente constituídas;

III. fornecer, à Secretaria de Recursos Humanos da UnB, órgão responsável pelo quadro de carreira dos servidores e prestadores de serviços do CESPE, os registros sobre sua conduta ética, para o efeito de instruir e fundamentar todos os procedimentos próprios da carreira do servidor público ou do prestador de serviços.

Art. 17. À Ouvidoria compete:

I. examinar manifestações referentes a procedimentos e ações de agentes, Gerências, Coordenadorias e Diretorias do CESPE;

II. propor a adoção de medidas para a prevenção e a correção de falhas e omissões dos responsáveis pela inadequada prestação dos serviços do CESPE;

III. produzir estatísticas indicativas do nível de satisfação dos usuários dos serviços prestados pelo CESPE, a partir de manifestações recebidas;

IV. contribuir com a disseminação das formas de participação popular no acompanhamento e fiscalização da prestação dos serviços públicos;

V. produzir índices e indicadores de produtividade e qualidade, na interpretação de seus resultados, na prospecção das soluções tecnológicas relevantes.

Art. 18. Ao Comitê Executor compete:

I. reunir-se, quinzenalmente, visando a buscar a integração e a troca de experiências de todos os setores envolvidos no processo logístico e de execução;

II. acompanhar o desdobramento das rotinas e dos processos dos eventos agendados;

III. planejar, dirigir e orientar a execução das atividades desenvolvidas pelo CESPE.

Art. 19. Aos Centros Regionais compete:

I. dirigir, coordenar, controlar e avaliar as atividades de condução dos processos/concursos realizados pelo CESPE no âmbito de sua região;

II. identificar instituições que podem ter suas instalações utilizadas como local de aplicação de provas, selecionando as que serão utilizadas em cada processo;

III. manter sempre atualizado cadastro de instituições utilizadas como local de aplicação de provas;

IV. recrutar, selecionar e treinar os colaboradores que trabalharão em cada processo, priorizando, no recrutamento, professores, técnico-administrativos e alunos de instituições superiores de ensino;

V. manter atualizado cadastro de colaboradores que possam participar de processos de aplicação de provas;

VI. inspecionar e orientar a preparação das instalações que serão utilizadas para a aplicação de provas, de forma que estejam de acordo com as especificações do CESPE; 
VII. recepcionar os integrantes da equipe do CESPE que participarão do processo naquela localidade, prestando-lhes o apoio logístico necessário.

Art. 20. Às Gerências compete:

I. planejar, coordenar, executar e avaliar o desenvolvimento dos projetos relativos à sua área de atuação, promovendo estudos em função dos cenários, das inovações, das tendências e da necessidade dos clientes;

II. gerenciar projetos, com autonomia e flexibilidade, de modo a garantir os resultados;

III. manter um membro permanente no Comitê Executor.

\section{CAPÍTULO IV}

Das Atribuições dos Dirigentes

Art. 21. O Diretor-Geral tem como atribuições:

I. assistir o Reitor da UnB em assuntos pertinentes à área de competência do Centro de Seleção e de Promoção de Eventos;

II. representar o CESPE, ou fazer-se representar, em órgãos de deliberação coletiva, em grupos de trabalho, em comissões e em discussões nacionais ou internacionais de interesse da UnB;

III. propor à Reitoria da UnB a assinatura de contratos, de convênios e de outros instrumentos similares que atendam aos objetivos da Instituição e do CESPE;

IV. dirigir, planejar, supervisionar, promover, coordenar, orientar e controlar a execução das atividades do CESPE;

V. estabelecer, em organograma, as subordinações e hierarquias das unidades do CESPE;

VI. regulamentar os assuntos necessários ao desenvolvimento das ações do CESPE mediante atos da Diretoria-Geral ou outros atos administrativos;

VII. ordenar despesas, assinar notas de empenho e ordens bancárias, no âmbito do CESPE;

VIII. homologar licitações, declarar a inexigibilidade de licitações, dispensar licitações na forma da legislação vigente e assinar contratos administrativos ou outros instrumentos;

IX. aprovar a execução de projetos do CESPE;

X. autorizar viagens, a serviço, dos titulares das unidades do CESPE;

XI. autorizar férias regulamentares dos titulares das unidades do Centro;

XII. autorizar a concessão de diárias, de hospedagens e de passagens;

XIII. autorizar a participação de servidores em convênios e contratos e a contratação de prestadores de serviços, em caráter eventual;

XIV.homologar ou referendar atos vinculados à competência do CESPE;

XV. subdelegar competências;

XVI.coordenar as atividades relacionadas à Ouvidoria;

XVII. praticar os demais atos necessários à gestão do Centro.

Art. 22. O Diretor-Executivo tem como atribuições:

I. assistir a Diretoria-Geral do CESPE em assuntos pertinentes à área de competência da Diretoria-Executiva;

II. dirigir, planejar, supervisionar, promover, coordenar, orientar, controlar e avaliar as atividades de sua área de atuação; 
III. implementar políticas relativas a serviços técnico-especializados;

IV. articular interna e externamente as ações necessárias ao pleno e eficaz funcionamento do CESPE;

V. aprovar planos e programas de trabalho apresentados pelos Coordenadores e Gerentes;

VI. coordenar a elaboração de relatórios de atividades do CESPE;

VII. praticar atos de administração orçamentária e financeira;

VIII. conceder suprimentos de fundos e aprovar as respectivas prestações de contas;

IX. autorizar requisição, permuta, cessão e baixa de materiais e de bens patrimoniais, respeitada a legislação vigente;

X. indicar à Diretoria-Geral do CESPE servidor a ser designado para atuar como co-responsável pelos atos da Diretoria-Executiva, no que diz respeito à execução orçamentária e financeira.

Art. 23. Aos Coordenadores e Gerentes incumbe:

I. baixar normas regulamentadoras relativas a sua área de atuação, após a aprovação da Direção-Geral, além de outras atribuições que lhes forem delegadas;

II. dirigir, planejar, promover, supervisionar, coordenar, orientar, controlar e avaliar as atividades de suas respectivas áreas de atuação.

Art. 24. Aos Assessores Técnicos, Secretário Administrativo, Ouvidor e aos Coordenadores de Centros e Comitês incumbe dirigir, supervisionar, coordenar, executar, controlar e avaliar as atividades das respectivas unidades, praticando os atos inerentes ao exercício de suas atribuições e os que lhes forem delegados.

\section{CAPÍTULO V}

Das Disposições Gerais

Art. 25. Os casos omissos e as dúvidas surgidas na aplicação da presente estrutura organizacional serão solucionados pelo Diretor-Geral do CESPE.

\section{Organograma do CESPE/UnB}

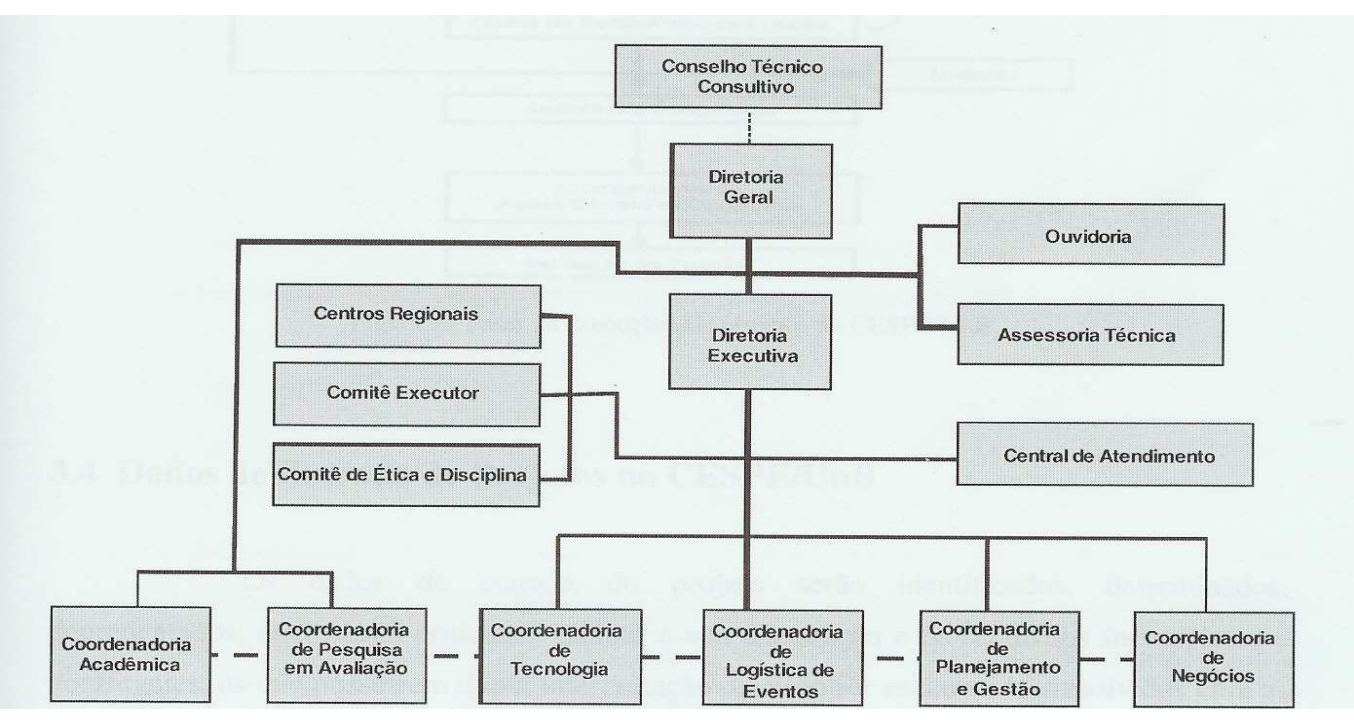

Figura 2 - Organograma do CESPE/UnB 


\subsection{Os serviços oferecidos pelo CESPE/UnB à sociedade e a captação de recursos complementares para a UnB}

O Centro de Seleção e de Promoção de Eventos da UnB apresenta no seu portfólio os seguintes serviços:

- Processos seletivos e concursos públicos

- Avaliações educacionais e de programas

- Seleções simplificadas

- Testes de proficiência

- Construção de bancos de itens (questões)

- Cursos de formação e capacitação

- Organização de eventos

- Projetos e consultorias

\subsection{Fluxo dos procedimentos relativos aos processos seletivos e concursos públicos}

Entre as principais atividades desenvolvidas pelo CESPE/UnB estão os Processos Seletivos e Concursos Públicos. Faz-se a seguir uma breve descrição de seus procedimentos macros, que demonstram toda a complexidade dos trabalhos executados pelo Centro e as necessárias competências técnicas exigidas. Tal complexidade impõe a cada dia a melhoria contínua desses procedimentos.

O carro chefe do Centro, segundo o seu Diretor-Geral, é a organização de concursos públicos, cujas fases principais do processo podem ser assim esquematizadas:

1) Negociação

- Contrato

- Edital

- Estabelecimento dos parâmetros de avaliação:

- Delineamento dos instrumentos

- Estabelecimento dos critérios de seleção/classificação

- Definição dos objetos de conhecimento a serem avaliados

- Estabelecimento das ênfases

- Cronograma

2) Divulgação 
- Publicação de editais

- Plano de mídia

- Confecção de cartazes

- Distribuição de panfletos

3) Descrição

- Desenvolvimento de sistema

- Contratação de postos que permitem acesso à Internet

- Contato com rede bancária

- Contratação de coordenadores regionais

- Acompanhamento do processo

- Impressão de material

4) Contratação de bancas

- Análise de perfil dos cargos

- Montagem do mapa/matriz de composição das provas

- Adaptação do manual de elaboração/revisão

- Contratação de especialistas

- Assinatura de termo de compromisso

- Treinamento nas técnicas de elaboração

5) Elaboração de itens

- Concepção da prova

- Elaboração de itens

- Revisões linguiísticas

- Ajuste técnico e pedagógico

- Calibragem de itens

- Estruturação da prova

- Leitura crítica e de sensibilidade

- Revisão lingüística

- Liberação final da banca

- Liberação da versão final para impressão

- Checagem da integridade

6) Preparação da logística de aplicação

- Geração do quantitativo de inscritos por cargo/cidade de prova, após a comprovação bancária 
- Envio de correspondência para os não-homologados

- Seleção e contratação de espaço físico

- Análise das solicitações de atendimento especial

- Envio das adaptações solicitadas para Coordenadoria Acadêmica e para Logística

- Dimensionamento e contratação de pessoal para aplicação

- Envio de correspondência para ADPF e PRF

- Distribuição dos candidatos nos locais

- Elaboração de edital de distribuição

- Envio de boletim informativo para todos os inscritos

7) Impressão e empacotamento de material sigiloso, incluindo a geração dos tipos de provas e a adaptação e impressão de provas especiais

8) Impressão e empacotamento de materiais diversos

- boletins de local e horário

- formulários de controle de aplicação,

- listas de freqüência,

- folhas de respostas e de textos definitivos,

- manuais de aplicadores,

- material de sinalização.

- material de aplicação

- caixas de coordenação

- malotes e lacres

- Termos de abertura e fechamento

9) Treinamento de coordenadores e aplicadores de prova

- Criação de manuais de aplicação para

- Coordenadores

- Assistentes de coordenação

- Delegados

- Chefes de sala e fiscais

- Equipe de segurança

- Equipe de atendimento especial

- Equipe de apoio

- Treinamentos/capacitação

10) Plano de aplicação e distribuição 
- Emissão de passagens e reservas

- Contratação de transporte (sala-cofre -> aeroporto -> local de guarda -> local de aplicação)

- Visita aos locais na véspera e conferência da distribuição e treinamento de aplicadores locais

11) Segurança no dia da aplicação

- Rastreamento de sinais de comunicação (parceria com a Associação dos Delegados de Polícia Federal - ADPF)

- Circulação de veículos nas áreas próximas aos locais de provas monitorando ondas eletromagnéticas, com a intenção de detectar tentativas de comunicação eletrônica entre candidatos e pessoas externas.

12) Dia da aplicação

- Busca do material sigiloso no local guardado

- Chegada ao local com vistoria/rastreamento eletrônico

- Revisão de pontos importantes relativos à aplicação com a equipe

- Aplicação das provas

- Desidentificação do material

- Lacre e guarda de malotes

- Viagem

- Retorno à área sigilosa do Cespe/UnB

13) Pagamentos

- Pagamento das equipes

- Pagamentos diversos (espaço físico, transporte, lanche etc.)

14) Conferência, processamento

- Recebimento e abertura do material

- Leitura de atas/formulários de controle da aplicação

- Digitalização e interpretação

- Candidatos especiais

- Divulgação de gabarito provisório

- Desenvolvimento de sistema de recursos

- Contratação de bancas

- Revisão das respostas das bancas

15) Correção (desenvolvimento de sistemas) de 
- Provas objetivas

- Provas discursivas

- Treinamento de bancas para estabelecimento de padrão de respostas esperado e correção da amostra

- Digitalização dos textos e adaptação do sistema

- Divulgação de espelhos de correção e análise de recursos

16) Elaboração de editais de resultado final

- Elaboração de relatórios finais

- Candidatos especiais

- Candidatos sub-judice

- Desenvolvimento de sistemas de consulta de resultados, de cópias das folhas de respostas/textos e de geração de boletim de desempenho

17) Auditoria dos processos

18) Outras etapas possíveis

- Avaliação de títulos

- Prova oral

- $\quad$ Defesa de memorial

- Prova prática

- Prova de digitação

- Avaliação psicológica

- Testes de capacidade física

- Avaliação de vida pregressa

- Exames médicos

- Cursos de formação

No planejamento destas atividades são previstos recursos para cobrir as despesas de cada etapa. Verifica-se que a maior concentração dos gastos está vinculada ao pagamento de pessoas físicas, internas e externas à FUB.

Estes pagamentos estão devidamente regulamentados em normas internas, observada a legislação pertinente, a doutrina acerca da matéria e a farta jurisprudência do Tribunal de Contas da União (TCU). 
As normas de captação e gestão de recursos financeiros por meio de convênios e contratos estão regulamentadas pela Resolução do Conselho de Administração da Universidade de Brasília n. 001/98, de 29 de julho de 1998, cujo art. 1. determina que "As Unidades Acadêmicas, Administrativas e Complementares da UnB, devem considerar, como parte de suas atividades, o esforço permanente na captação de recursos". O art. 9. da mesma resolução garante a possibilidade de participação remunerada, à conta dos recursos captados, dos docentes e técnicos administrativos, sem prejuízo das atividades dos cargos que ocupam na instituição e respeitadas as respectivas cargas horárias (UnB, 1998, p.1 a 4).

O limite dos valores das remunerações por prestação de serviço é fixado por resolução específica da Reitoria, atualmente, em vigor a Resolução n ${ }^{\circ}$ 48/2007, de 11 de julho de 2007.

$\mathrm{Na}$ forma regulamentada pela UnB, os serviços oferecidos à sociedade, são projetos específicos, formalizados por meio de contratos. A realização do Vestibular e de outras formas de acesso à UnB, assim como os concursos para provimento de seus cargos, devem obedecer o que dispõe o Decreto n. 6.114/07, de 15 de maio de 2007, que regulamentou o pagamento da gratificação por encargo de curso ou concurso de que trata o Art. 76-A, da Lei n. 8.112/90, de 11 de novembro de 1990 (BRASIL, 1990, p 31).

Os critérios para o pagamento a todos que cumprem tarefas levam em consideração a disponibilidade orçamentária e financeira, a complexidade das atividades desenvolvidas, o grau de sigilo, a carga horária do trabalho, o nível de responsabilidade, a experiência e a capacitação profissional, respeitados os limites fixados nas referidas normas.

É bom comentar que não pode a FUB pretender que qualquer pessoa, servidora ou não, lhe preste serviços nos fins de semana em horários que seriam destinados ao descanso e ao exercício de atividades particulares, sem pagar por esta dedicação extraordinária e específica, neste sentido é o entendimento do colendo TCU, in verbis:

\footnotetext{
DECISÃO 473/1996 - Plenário

Nome do Documento

DC-0473-30/96-P
}

Ementa

Denúncia formulada por pessoa física ä Ouvidoria-Geral da República e encaminha ao TCU contra a FUB. Remuneração de servidores pela participação na execução de contratos e convênios firmados pela Fundação. Pagamento de Gratificação Poe Encargos de Curso ou Concurso. Comprovação dos fatos. Conhecimento. Determinação.

Decisão

O Tribunal Pleno, diante das razões expostas pelo Relator, DECIDE:

1. conhecer da presente denúncia, para no mérito julgá-la procedente; 
2. determinar à FUB que:

2.1. abstenha-se de remunerar adicionalmente seus servidores pela mera participação na execução de contratos/convênios celebrados pela Entidade, ressalvados os casos de prestação de serviços extraordinários, previsto no art. 61, V, da Lei n. 8.112/90, e de eventual realização de atividades não inerentes ao seu quadro próprio de pessoal, desde que tais atividades sejam definidas com clareza e objetividade e desenvolvidas fora do horário de expediente sem prejuízo das atribuições regulares dos servidores beneficiários;

2.2. discipline, no âmbito da Fundação o pagamento da Gratificação por Encargo de Curso ou Concurso, instituída pelo art. 8. do Decreto-Lei n. 1.604/78, com redação dada pelo art. 4. Do Decreto-lei n. 1.746/79, observado, em especial, que:

2.2.1. os valores da gratificação devem se fixados pela Administração da FUB e observados uniformemente por todas as suas unidades setoriais envolvidas, nos limites do referido Decreto-lei n. 1.746/79;

2.2.2. apenas poderão ser beneficiados com a gratificação os servidores que, na forma do disposto no anexo II, item XX, do Decreto-lei n. 1.341/74, com redação dada pelo Decreto-lei n. 1.746/79, desempenharem atividades eventuais de apoio à realização de cursos ou concursos, e desde que sem prejuízo de suas atribuições normais, vedado o pagamento da gratificação aos servidores que se dedicam a tais eventos em caráter permanente;

2.3. adéqüe a Resolução FUB n. 008/92, alterada pela Resolução da Reitoria n. $116 / 93$, no que couber, às determinações dos itens anteriores;

3. determinar à CISET/MEC que consigne no Relatório de Auditoria relativo às próximas contas da Entidade as providências adotadas pela FUB a respeito;

4. encaminhar cópia desta Decisão, bem como do Relatório e Voto que a fundamentam, ao interessado e à Ouvidoria-Geral da República do Ministério da Justiça;

5. cancelar a chancela de sigilo aposta ao processo;

6. determinar à $6^{\mathrm{a}}$. SECEX a juntada do presente processo às contas da Entidade, exercício de 1996, para exame em confronto.

Publicação

Sessão 31/07/1996

DOU 19/08/1996 - Página 15.819

Em acatamento aos Órgãos de Controle, interno e externo, os instrumentos contratuais, hoje, utilizados para participação nos projetos executados pelo CESPE/UnB são os seguintes: 


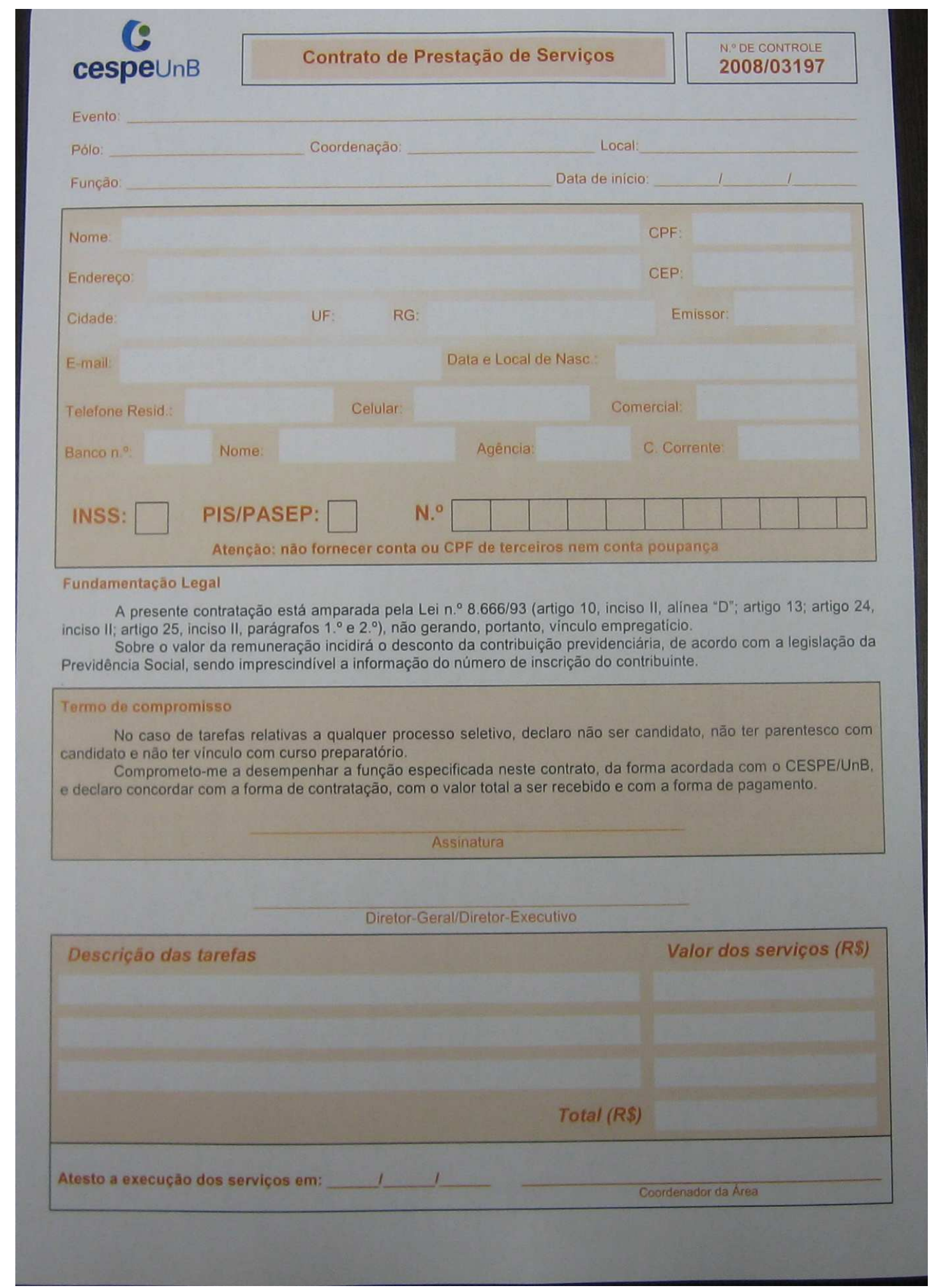

Figura 3 


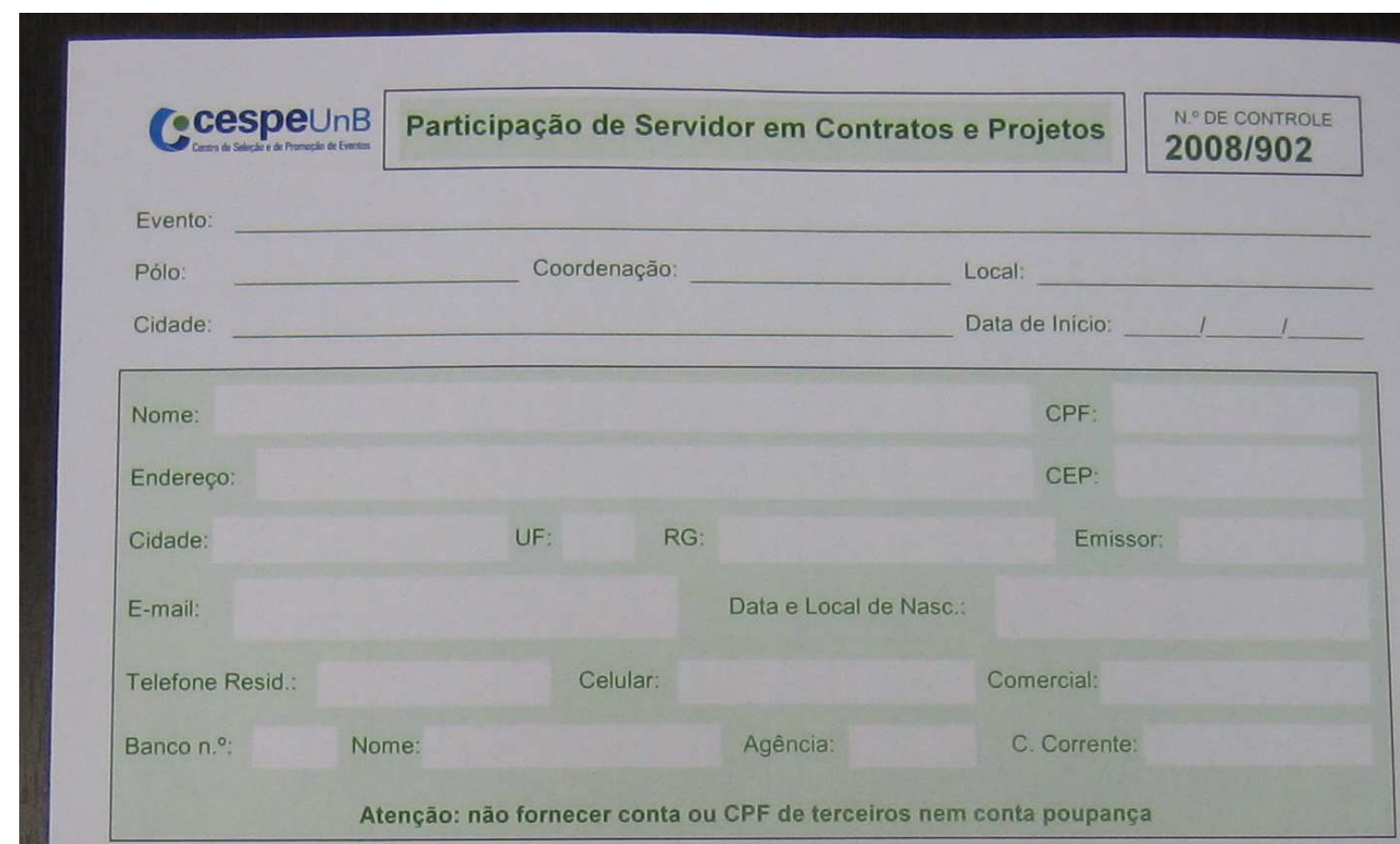

Fundamentação Legal

A presente participação tem fundamento no artigo 207 da Constituição Federal, no artigo 53 da Lei n. ${ }^{\circ} 9.394 / 96$, na decisão do TCU n. ${ }^{\circ}$ 473/96, na Resolução do Conselho de Administração $n .{ }^{\circ} 001 / 98$ e na Resolução da Reitoria $n .{ }^{\circ}$ $24 / 2007$.

Termo de compromisso

No caso de tarefas relativas a qualquer processo seletivo, declaro não ser candidato, não ter parentesco com candidato e não ter vínculo com curso preparatório.

Comprometo-me a desempenhar a função especificada neste contrato fora do horário normal de trabalho, da forma acordada com o CESPE/UnB, e declaro concordar com a forma de contratação, com o valor total a ser recebido e com a forma de pagamento.

\section{Diretor-Geral/Diretor-Executivo}

\section{Descrição das tarefas}

Figura 4 


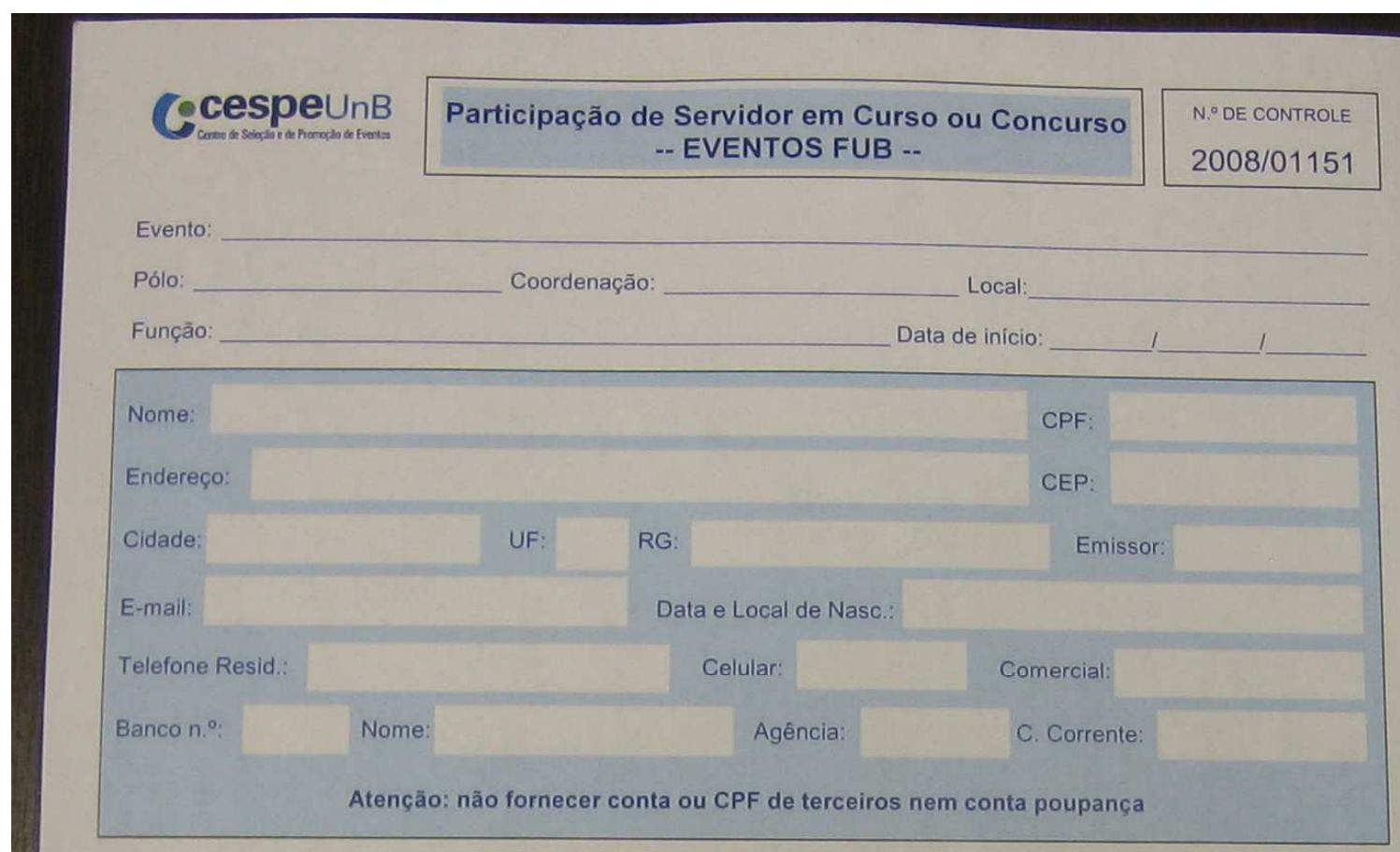

Fundamentação Legal

A presente participaçāo tem fundamento no artigo 207 da Constituição Federal, nos artigos 76-A e 98 da Lei n. ${ }^{\circ}$ 8.112/90, no artigo 53 da Lei $n .{ }^{\circ} 9.394 / 96$, na decisão do TCU n. ${ }^{\circ} 473 / 96$, na Resolução do Conselho de Administração n. ${ }^{\circ} 001 / 98$ e na Resolução da Reitoria n. ${ }^{\circ} 24 / 2007$.

\section{Termo de compromisso}

No caso de tarefas relativas a qualquer processo seletivo, declaro não ser candidato, não ter parentesco com candidato e nảo ter vínculo com curso preparatório.

Comprometo-me a desempenhar a função especificada neste contrato fora do horário normal de trabalho, da forma acordada com o CESPE/UnB, e declaro concordar com a forma de contratação, com o valor total a ser recebido e com a forma de pagamento.

\section{Assinatura}

\section{Diretor-Geral/Diretor-Executivo}

\begin{tabular}{|l|l|}
\hline Descrição das tarefas & Dias trabalhados Horário \\
\hline Atesto a execução dos serviços em: & Valor da participaçăo (RS) \\
\hline
\end{tabular}

Figura 5 


\section{PESQUISA DE CAMPO}

\subsection{Metodologia}

Com a finalidade de estudar a gestão da captação de recursos no âmbito do CESPE/UnB, realizou-se a pesquisa empírica, devidamente tratada na metodologia a seguir. Após o que, apresentam-se considerações que podem influir nos processos de melhoria contínua dos trabalhos executados pelo CESPE/UnB, e até servir de instrumento para avaliar permanentemente a qualidade dos bens e serviços produzidos pelo órgão. A expectativa final é a de que o presente trabalho estimule a reestruturação dos processos de planejamento institucional que vêm sendo adotados pela Diretoria do CESPE/UnB, após críticos e profundos exames de cada uma das áreas de sua estrutura funcional e dos resultados alcançados.

A presente metodologia aponta as técnicas de pesquisa adotadas no mapeamento dos processos utilizados pelo CESPE/UnB para consecução de seus objetivos institucionais, com o fim de analisá-los, e descreve o tipo de pesquisa, a população-alvo, o instrumento aplicado, os procedimentos adotados e a forma de análise dos dados coletados.

\subsubsection{Tipo de pesquisa}

Trata-se de pesquisa qualitativa e descritiva, com base em entrevista, na qual os coordenadores, os gerentes e um colaborador de área do CESPE/UnB indicaram pontos positivos e de excelência nos processos de trabalho que desenvolvem e o que poderiam tornálos ainda melhor. A pesquisa não tratou de pontos fracos, embora o estudo tenha propiciado reflexões sobre o tema.

A pesquisa utilizada foi bibliográfica (documental) e de campo. A pesquisa bibliográfica fundamentou a parte teórica do estudo e realizou-se a coleta dos dados por meio da pesquisa de campo no CESPE/UnB, cenário do fenômeno investigado.

\subsubsection{População-alvo}

$\mathrm{O}$ universo da pesquisa foi a alta administração do CESPE/UnB, que inclui as Diretorias Geral e Executiva e as Coordenadorias Acadêmica, de Pesquisa em Avaliação, de Logística, de Tecnologia, de Educação Corporativa e de Negócios. 
Participaram da pesquisa os dois diretores, Geral e Executivo, coordenadores, gerentes e colaboradores, garantindo-se ao menos um respondente de cada área do CESPE/UnB. Os colaboradores foram indicados pelos coordenadores de área entre ocupantes de cargos de nível superior.

\subsubsection{Instrumentos de coleta de dados}

As informações para identificar elementos que influenciam a melhoria constante nos processos de prestação de serviços e captação de recursos foram coletadas por meio de entrevistas individuais, semi-estruturadas, concebidas com base na estrutura básica oferecida por Günter (1996): a) identificação do pesquisador e legitimação dos objetos de pesquisa e b) uma estrutura lógica das temáticas apresentadas na coleta de dados.

O formulário da entrevista encontra-se no anexo deste trabalho.

Segundo Gil (1999), entrevista é a técnica em que o investigador se apresenta frente ao respondente e lhe formula perguntas, com o objetivo de obtenção dos dados que interessam à investigação. Essa técnica é utilizada não apenas para coleta de dados, mas também com objetivos voltados para diagnóstico e orientação. É uma técnica muito eficiente para obtenção de dados em profundidade.

Considerando-se que a entrevista semi-estruturada ocorre a partir de um esquema básico, porém não aplicado com rigor, permite-se ao entrevistador realizar as adaptações que julgar necessárias e convenientes. Entende-se que esta modalidade vem ao encontro da necessidade da pesquisa.

\subsubsection{Procedimento de coleta}

A realização da pesquisa de campo, no âmbito do CESPE/UnB, ocorreu em dias e horários definidos pela Diretoria-Geral do CESPE/UnB, mediante a aplicação pessoal dos pesquisadores.

Antes de cada entrevista foi feita uma explicação prévia do objetivo acadêmico do trabalho, além de garantido aos indivíduos participantes o sigilo total e absoluto sobre o conteúdo das informações coletadas, assim como um compromisso quanto ao conhecimento do resultado do trabalho. 


\subsection{Resultados}

\subsubsection{Definição e caracterização da população}

No presente estudo tratou-se de conhecer a opinião da alta direção do CESPE/UnB, mediante entrevistas, nas quais os respondentes, de forma individualizada, deram suas opiniões sobre assuntos relacionados à análise do ambiente externo ao CESPE/UnB (identificação dos eventos condicionantes do futuro: mundiais, nacionais, regionais), com base em dados estatísticos sobre a situação corrente e a evolução dos eventos, as ameaças e as oportunidades nos campos político, econômico, tecnológico, social, cultural e ambiental; e à análise do ambiente interno ao CESPE/UnB, considerando, nesse caso, o estudo e a avaliação dos pontos fortes do ambiente interno da organização e dos seus impactos e/ou influências dos eventos externos nas atividades desenvolvidas pelo CESPE/UnB.

\subsubsection{Tratamento dos dados}

O conteúdo das informações obtidas foi categorizado. A formulação de categorias, em análise de conteúdo, é, por natureza, um processo longo, difícil e desafiante, mesmo quando o problema está claramente definido e as hipóteses satisfatoriamente delineadas (FRANCO, 2003).

Nesse contexto, utilizou-se as categorias definidas como análise ambiental interna e externa no trabalho intitulado Gestão Estratégica de Universidade, o caso da FA/UnB (MARCELINO, 2004), que adequou-se perfeitamente ao caso em estudo.

No presente estudo, a análise ambiental interna procurou identificar os pontos fortes do CESPE/UnB, a fim de otimizá-los para aproveitar ainda mais as oportunidades externas que surgirem e evitar que elas fiquem vulneráveis às ameaças externas.

Já a análise ambiental externa diz respeito ao contexto sócio-político-econômico e cultural do país e do mundo que afeta todas as organizações e especificamente ao CESPE/UnB: concorrentes, clientes, fornecedores, colaboradores e outros. 


\subsubsection{Análise dos dados}

A análise dos dados foi realizada com base na técnica de análise de conteúdo proposta por Bardin (1977). Esta técnica propõe uma análise baseada no discurso do entrevistado, que possui significados próprios, além daqueles que podem ser anteriormente pressupostos, e tem como objetivo a sistematização do conteúdo da mensagem transmitida pelo entrevistado.

Neste contexto, foi realizada a categorização - considerada por Franco (2003) como o ponto crucial da análise de conteúdo - das verbalizações dos entrevistados por meio do agrupamento de núcleos de sentido, isto é, as categorias são compostas por temas que apresentam semelhanças e coerência entre seus significados (BARDIN, 1977).

De acordo com Bardin (1977) e Franco (2003), as categorias podem ser definidas a priori - antes da realização das entrevistas, tendo como base o referencial teórico e o interesse de pesquisa do entrevistador - ou a posteriori - a partir do conteúdo exposto pelo entrevistado, e posteriormente comparadas ao referencial teórico do pesquisador. Neste estudo, serão utilizadas categorias a posteriori, visto que categorias previamente definidas podem limitar a entrevista e a análise dos dados (FRANCO, 2003).

Bardin (1977) sugere, ainda, que as análises sejam realizadas por três juízes; entretanto, pelo fato de a pesquisa ter tempo delimitado, a análise foi realizada apenas por um juiz.

\section{Categoria 1 - Perfil}

A entrevistada tem mestrado completo e é gerente do Cespe. Sua área é responsável por análises estatísticas e confecção de relatórios. Conta que, para captar recursos, o Cespe oferece serviços como realização de concursos públicos, cursos de capacitação, avaliações educacionais, certificação e avaliação de programas.

Tabela 2 - Respondente 1 - Categoria 1 - Perfil

\begin{tabular}{|l|l|c|}
\hline Verbalização & Tema & Freq. \\
\hline Gerente & Cargo no Cespe & 1 \\
\hline Mestrado completo & Escolaridade & 1 \\
\hline $\begin{array}{l}\text { Realização de concursos públicos, cursos de capacitação, avaliações } \\
\text { educacionais, certificação e avaliação de programas. }\end{array}$ & $\begin{array}{l}\text { Serviços para captação } \\
\text { de recursos }\end{array}$ & 1 \\
\hline Análises estatísticas e confecção de relatórios. & Processos da área & 1 \\
\hline \multicolumn{1}{|c|}{ TOTAL: 4 } \\
\hline
\end{tabular}




\section{Categoria 2 - Pontos fortes e melhorias}

A entrevistada acredita que os pontos fortes do Cespe são o "estudo e atualização constantes", bem como "o intercâmbio com pesquisadores e o trabalho em equipe". Acredita que, como melhorias, o Cespe pode prover "mais investimento na parte tecnológica e pessoal especializado em programação". Considera "a área da Testagem Adaptativa Computadorizada como algo que mereça investimentos para um futuro próximo".

Tabela 3 - Respondente 1 - Categoria 2 - Pontos fortes e melhorias

\begin{tabular}{|l|l|c|}
\hline Verbalização & Tema & Freq. \\
\hline Podem ser melhorados com mais investimentos na parte tecnológica & Tecnologia & 1 \\
\hline Pessoal especializado em programação. & Pessoal especializado & 1 \\
\hline Estudo e atualização constantes. & Atualização & 1 \\
\hline $\begin{array}{l}\text { Também é muito positivo o intercâmbio com pesquisadores e o trabalho } \\
\text { em equipe. }\end{array}$ & Intercâmbio & 1 \\
\hline $\begin{array}{l}\text { Quanto a oportunidades vislumbradas, vejo a área da Testagem } \\
\text { Adaptativa Computadorizada como algo que mereça investimentos para } \\
\text { um futuro próximo. }\end{array}$ & Oportunidades & 1 \\
\hline \multicolumn{2}{|c|}{ TOTAL: 5 } \\
\hline
\end{tabular}

\section{Categoria 1 - Perfil}

O entrevistado ocupa o cargo de Técnico em Assuntos Educacionais tanto na FUB como no Cespe. Sua escolaridade é ensino superior incompleto. Relata que sua área desenvolve processos de "execução contábil, orçamentária, financeira, análise de processos referente a recebimentos de recursos financeiros e pagamentos (pessoa física e jurídica) e elaboração de relatórios gerenciais". Para captar recursos, conta que o Cespe realiza serviços como "processos seletivos para admissão em órgãos públicos, avaliações (...) e cursos de formação para os candidatos aprovados”.

Tabela 4 - Respondente 2 - Categoria 1 - Perfil

\begin{tabular}{|l|l|c|}
\hline Verbalização & Tema & Freq. \\
\hline Técnico em Assuntos Educacionais & Cargo na FUB & 1 \\
\hline Técnico em Assuntos Educacionais & Cargo no Cespe & 1 \\
\hline Terceiro Grau - incompleto & Escolaridade & 1 \\
\hline $\begin{array}{l}\text { Processos seletivos para admissão em órgãos públicos, avaliações, } \\
\text { (ENEM, ENADE, PISA, ENCCEJA) e cursos de formação para os } \\
\text { candidatos aprovados. }\end{array}$ & $\begin{array}{l}\text { Serviços para captação } \\
\text { de recursos }\end{array}$ & 1 \\
\hline $\begin{array}{l}\text { Execução contábil, orçamentária, financeira, análise de processos } \\
\text { referente a recebimentos de recursos financeiros e pagamentos (pessoa } \\
\text { física e jurídica) e elaboração de relatórios gerenciais. }\end{array}$ & Processos da área & 1 \\
\hline \multicolumn{2}{|c|}{ TOTAL: 5 } \\
\hline
\end{tabular}




\section{Categoria 2 - Pontos Fortes e Melhorias}

O entrevistado considera como pontos positivos de sua área "a responsabilidade e comprometimento dos funcionários (...) com a relação ao sigilo dos dados, ética e legalidade nos processos tramitados no setor". Acredita que estas características são fundamentais para a realização do trabalho dentro das normas, assim como o planejamento e a comunicação entre os setores, que considera que são pontos a serem melhorados. Também acredita que poderia ser oferecida maior qualificação aos funcionários. Por trabalhar em uma área administrativa, não vê "no contexto nacional oportunidades para atuar".

Tabela 5 - Respondente 2 - Categoria 2 - Pontos fortes e melhorias

\begin{tabular}{|l|l|c|}
\hline Verbalização & Tema & Freq. \\
\hline Qualificação, treinamento dos funcionários do setor & Qualificação & 1 \\
\hline planejamento de modo geral nas atividades desenvolvidas pelo órgão. & Planejamento & 2 \\
\hline $\begin{array}{l}\text { Considerando a minha área fim, é indispensável o planejamento, a } \\
\text { comunicação entre os setores }\end{array}$ & & 2 \\
\hline $\begin{array}{l}\text { A responsabilidade e comprometimento dos funcionários que trabalham } \\
\text { na área com a relação ao sigilo dos dados, ética e legalidade nos } \\
\text { processos tramitados no setor. }\end{array}$ & Comprometimento & \\
\hline $\begin{array}{l}\text { o grau de responsabilidade e comprometimento nas atividades } \\
\text { desenvolvidas pelo órgão, para que possamos atender plenamente as } \\
\text { normas vigentes. }\end{array}$ & & 1 \\
\hline $\begin{array}{l}\text { Considerando que é uma área administrativa, não vejo no contexto } \\
\text { nacional oportunidades para atuar. }\end{array}$ & Oportunidades & TOTAL: 6 \\
\hline \multicolumn{1}{|l}{}
\end{tabular}

\section{Categoria 1 - Perfil}

O entrevistado tem pós-graduação (MBA) e ocupa o cargo de Programador de Computador na FUB, e de Coordenador de Tecnologia no Cespe. Sua área é responsável pela geração e correção de concursos. Ele relata que, para captar recursos, o Cespe oferece serviços como concursos públicos e seleções, cursos de formação e avaliações.

Tabela 6 - Respondente 3 - Categoria 1 - Perfil

\begin{tabular}{|l|l|c|}
\hline Verbalização & Tema & Freq. \\
\hline Programador de Computador & Cargo na FUB & 1 \\
\hline Coordenador de Tecnologia & Cargo no Cespe & 1 \\
\hline Pós-Graduação - MBA & Escolaridade & 1 \\
\hline Concursos públicos e seleções, cursos de formação e avaliações. & $\begin{array}{l}\text { Serviços para captação } \\
\text { de recursos }\end{array}$ & 1 \\
\hline Geração e correção de concursos. & Processos da área & 1 \\
\hline \multicolumn{1}{|c|}{ TOTAL: 5 } \\
\hline
\end{tabular}




\section{Categoria 2 - Pontos Fortes e Melhorias}

O entrevistado vê como pontos fortes de sua área a qualificação e o comprometimento da equipe, "gerando resultados precisos". Acredita que o Cespe deve aperfeiçoar suas ferramentas e seus procedimentos e atualizar as metodologias que utiliza, tendo em vista a melhoria dos processos administrativos e a redução do desgaste "que hoje é gerado pela grande quantidade de eventos".

Tabela 7 - Respondente 3 - Categoria 2 - Pontos fortes e melhorias

\begin{tabular}{|l|l|c|}
\hline Verbalização & Tema & Freq. \\
\hline $\begin{array}{l}\text { Aperfeiçoamento dos procedimentos e atualização das metodologias } \\
\text { utilizadas. }\end{array}$ & Atualização & 2 \\
\hline $\begin{array}{l}\text { Melhoramento e aperfeiçoamento das ferramentas e dos processos para } \\
\text { geração dos resultados, permitindo assim o CESPE/UnB participar de } \\
\text { muito mais processo sem o desgaste que hoje é gerado pela grande } \\
\text { quantidade de eventos. }\end{array}$ & & \\
\hline Qualificação & Qualificação & 1 \\
\hline $\begin{array}{l}\text { dedicação e comprometimento do corpo técnico, gerando resultados } \\
\text { precisos. }\end{array}$ & Comprometimento & 1 \\
\hline \multicolumn{2}{|c|}{ TOTAL: 4 } \\
\hline
\end{tabular}

\section{Categoria 1 - Perfil}

O entrevistado tem curso superior completo, é prestador de serviço e atua na área de Recursos Materiais e Patrimoniais. Sua área é responsável por prover recursos ao Cespe, além de elaborar procedimentos licitatórios "para a contratação de empresas para fornecerem bens e serviços que atenderão este Centro durante o ano". Afirma que, para captar recursos, o Cespe oferece serviços como concursos públicos, processos seletivos simplificados, cursos de formação e capacitação e processos de avaliações educacionais.

Tabela 8 - Respondente 4 - Categoria 1 - Perfil

\begin{tabular}{|l|l|c|}
\hline Verbalização & Tema & Freq. \\
\hline Sou prestador de serviço. & Cargo no Cespe & 1 \\
\hline Atuo na Área de Recursos Materiais e Patrimoniais. & Área de atuação & 1 \\
\hline Superior completo & Escolaridade & 1 \\
\hline $\begin{array}{l}\text { Concursos públicos, processos seletivos simplificados, cursos de } \\
\text { formação e capacitação e processos de avaliações educacionais. }\end{array}$ & $\begin{array}{l}\text { Serviços para } \\
\text { capacitação de recursos }\end{array}$ & 1 \\
\hline $\begin{array}{l}\text { A função desta área é prover o CESPE/UnB dos recursos necessários } \\
\text { (materiais e serviços) com vistas ao desenvolvimento de suas atividades } \\
\text { institucionais. Após conhecida a demanda dos eventos a serem } \\
\text { realizados, temos a obrigação em elaborar os procedimentos licitatórios } \\
\text { para a contratação de empresas para fornecerem bens e serviços que } \\
\text { atenderão este Centro durante o ano. }\end{array}$ & Processos da área & 1 \\
\hline \multicolumn{2}{|c|}{} & TOTAL: 5 \\
\hline
\end{tabular}




\section{Categoria 2 - Pontos Fortes e Melhorias}

O entrevistado considera como ponto forte de sua área o fato de sempre buscarem "a melhor formalização dos processos, com vistas a atender satisfatoriamente às exigências dos órgãos de controle". Acredita que o único ponto a ser melhorado é "somente e tão somente (...) um melhor planejamento". Por trabalhar em uma área meio, não encontra “oportunidades possíveis de serem exploradas pelo Cespe/UnB”.

Tabela 9 - Respondente 4 - Categoria 2 - Pontos fortes e melhorias

\begin{tabular}{|l|l|c|}
\hline Verbalização & Tema & Freq. \\
\hline Somente e tão somente com um melhor planejamento. & Planejamento & 1 \\
\hline $\begin{array}{l}\text { Buscar sempre a melhor a formalização dos processos, com vistas à } \\
\text { atender satisfatoriamente as exigências dos órgãos de controle. }\end{array}$ & $\begin{array}{l}\text { Busca da melhor } \\
\text { formalização dos } \\
\text { processos }\end{array}$ & 1 \\
\hline $\begin{array}{l}\text { Por se tratar de área meio, não encontro oportunidades possíveis de } \\
\text { serem exploradas pelo CESPE/UnB. }\end{array}$ & Oportunidades & 1 \\
\hline \multicolumn{1}{|c|}{ TOTAL: 3 } \\
\hline
\end{tabular}

\section{Categoria 1 - Perfil}

O entrevistado tem curso superior completo e doutorado, e é professor associado da FUB e Diretor-Geral do Cespe. Relata que os serviços prestados para captação de recursos são processos seletivos e concursos públicos, avaliações educacionais e de programas, seleções simplificadas, testes de proficiência, construção de bancos de itens, cursos de formação e capacitação, organização de eventos, projetos e consultorias. Ele conta que o carro chefe do Cespe é a organização de concursos públicos, e descreve todas as fases do processo: negociação, divulgação, inscrição, contratação de bancas, elaboração de itens, preparação da logística de aplicação, impressão e empacotamento de materiais sigilosos, impressão e empacotamento de materiais diversos, treinamento de coordenadores e aplicadores de prova, plano de aplicação e distribuição, segurança para aplicação de provas, procedimentos no dia de aplicação, pagamentos, conferência, processamento e batimento, correção, elaboração de editais de resultado final, auditoria e outras etapas possíveis.

Tabela 10 - Respondente 5 - Categoria 1 - Perfil

\begin{tabular}{|l|l|c|}
\hline Verbalização & Tema & Freq. \\
\hline Professor associado & Cargo na FUB & 1 \\
\hline Diretor-Geral & Cargo no Cespe & 1 \\
\hline Superior Completo - Doutorado & Escolaridade & 1 \\
\hline $\begin{array}{l}\text { Processos seletivos e concursos públicos, Avaliações Educacionais e } \\
\text { de Programas, Seleções simplificadas, Testes de proficiência, }\end{array}$ & $\begin{array}{l}\text { Serviços para captação de } \\
\text { recursos }\end{array}$ & 1 \\
\hline
\end{tabular}




\begin{tabular}{|c|c|c|}
\hline Verbalização & Tema & Freq. \\
\hline \multicolumn{3}{|l|}{$\begin{array}{l}\text { Construção de bancos de itens (questões), Cursos de formação e } \\
\text { capacitação, Organização de eventos, Projetos e consultorias }\end{array}$} \\
\hline O carro chefe do Centro é a organização de concursos públicos & "carro chefe do Centro" & 1 \\
\hline $\begin{array}{l}\text { Negociação: Contrato; Edital: Fases do processo: Estabelecimento dos } \\
\text { parâmetros de avaliação: Delineamento dos instrumentos, } \\
\text { Estabelecimento dos critérios de seleção/classificação, Definição dos } \\
\text { objetos de conhecimento a serem avaliados, Estabelecimento das } \\
\text { ênfases; Cronograma }\end{array}$ & $\begin{array}{l}\text { Processo de negociação } \\
\text { para concursos }\end{array}$ & 1 \\
\hline $\begin{array}{l}\text { Divulgação: Publicação de editais, Plano de mídia, Confecção de } \\
\text { cartazes, Distribuição de panfletos }\end{array}$ & $\begin{array}{l}\text { Processo de divulgação de } \\
\text { concursos }\end{array}$ & 1 \\
\hline $\begin{array}{l}\text { Inscrição: Desenvolvimento de sistema, Contratação de 'postos', } \\
\text { Contato com rede bancária, Contratação de coordenadores regionais, } \\
\text { Acompanhamento do processo, Impressão de material }\end{array}$ & $\begin{array}{l}\text { Processo de inscrição de } \\
\text { concursos }\end{array}$ & 1 \\
\hline $\begin{array}{l}\text { Contratação de bancas: Análise de perfil dos cargos, Montagem do } \\
\text { mapa/matriz de composição das provas, Adaptação do manual de } \\
\text { elaboração/revisão, Contratação de especialistas: Assinatura de termo } \\
\text { de compromisso; Treinamento nas técnicas de elaboração }\end{array}$ & $\begin{array}{l}\text { Processo de contratação } \\
\text { de bancas de concursos }\end{array}$ & 1 \\
\hline $\begin{array}{l}\text { Elaboração de itens: Concepção da prova, Elaboração de itens, } \\
\text { Revisões lingüísticas, Ajuste técnico e pedagógico, Calibragem de } \\
\text { itens, Estruturação da prova, Leitura crítica e de sensibilidade, } \\
\text { Revisão lingüística, Liberação final da banca, Liberação da versão } \\
\text { final para impressão, Checagem da integridade }\end{array}$ & $\begin{array}{l}\text { Processo de elaboração de } \\
\text { itens de concursos }\end{array}$ & 1 \\
\hline $\begin{array}{l}\text { Preparação da logística de aplicação: Geração do quantitativo de } \\
\text { inscritos por cargo/cidade de prova, após a comprovação bancária, } \\
\text { Envio de correspondência para os não-homologados, Seleção e } \\
\text { contratação de espaço físico, Análise das solicitações de atendimento } \\
\text { especial, Envio das adaptações solicitadas para Coordenadoria } \\
\text { Acadêmica e para Logística, Dimensionamento e contratação de } \\
\text { pessoal para aplicação, Envio de correspondência para ADPF e PRF, } \\
\text { Distribuição dos candidatos nos locais, Elaboração de edital de } \\
\text { distribuição, Envio de boletim informativo para todos os inscritos }\end{array}$ & $\begin{array}{l}\text { Processo de preparação da } \\
\text { logística de aplicação de } \\
\text { concursos }\end{array}$ & 1 \\
\hline $\begin{array}{l}\text { Impressão e empacotamento de material sigiloso, incluindo a geração } \\
\text { dos tipos de provas e a adaptação e impressão de provas especiais }\end{array}$ & $\begin{array}{l}\text { Impressão e } \\
\text { empacotamento de } \\
\text { materiais sigilosos de } \\
\text { concurso }\end{array}$ & 1 \\
\hline $\begin{array}{l}\text { Impressão e empacotamento de materiais diversos: boletins de local e } \\
\text { horário, formulários de controle de aplicação, listas de frequiência, } \\
\text { folhas de respostas e de textos definitivos, manuais de aplicadores, } \\
\text { material de sinalização, material de aplicação, caixas de coordenação, } \\
\text { malotes e lacres, Termos de abertura e fechamento }\end{array}$ & $\begin{array}{l}\text { Impressão e } \\
\text { empacotamento de } \\
\text { materiais de concurso } \\
\text { diversos }\end{array}$ & 1 \\
\hline $\begin{array}{l}\text { Treinamento de coordenadores e aplicadores de prova: Criação de } \\
\text { manuais de aplicação para Coordenadores, Assistentes de } \\
\text { coordenação, Delegados, Chefes de sala e fiscais, Equipe de } \\
\text { segurança, Equipe de atendimento especial, Equipe de apoio; } \\
\text { Treinamentos/capacitação }\end{array}$ & $\begin{array}{l}\text { Treinamento de } \\
\text { coordenadores e } \\
\text { aplicadores de prova de } \\
\text { concursos }\end{array}$ & 1 \\
\hline $\begin{array}{l}\text { Plano de aplicação e distribuição: Emissão de passagens e reservas, } \\
\text { Contratação de transporte (sala-cofre - aeroporto - local de guarda - } \\
\text { local de aplicação), Visita aos locais na véspera e conferência da } \\
\text { distribuição e treinamento de aplicadores locais }\end{array}$ & $\begin{array}{l}\text { Processo de planejamento } \\
\text { de aplicação e } \\
\text { distribuição para } \\
\text { concursos }\end{array}$ & 1 \\
\hline $\begin{array}{l}\text { Segurança no dia da aplicação: Rastreamento de sinais de } \\
\text { comunicação (parceria com a Associação dos Delegados de Polícia } \\
\text { Federal - ADPF), Veículos circulam nas áreas próximas aos locais de } \\
\text { provas monitorando ondas eletromagnéticas, com a intenção de } \\
\text { detectar tentativas de comunicação eletrônica entre candidatos e } \\
\text { pessoas externas. }\end{array}$ & $\begin{array}{l}\text { Procedimentos de } \\
\text { segurança para aplicação } \\
\text { de concursos }\end{array}$ & 1 \\
\hline Dia da aplicação: Busca do material sigiloso no local guardado, & Procedimentos para & 1 \\
\hline
\end{tabular}




\begin{tabular}{|c|c|c|}
\hline Verbalização & Tema & Freq. \\
\hline $\begin{array}{l}\text { Chegada ao local com vistoria/rastreamento eletrônico, Revisão de } \\
\text { pontos importantes relativos à aplicação com a equipe, Aplicação das } \\
\text { provas, Desidentificação do material, Lacre e guarda de malotes, } \\
\text { Viagem, Retorno à área sigilosa do Cespe/UnB }\end{array}$ & $\begin{array}{l}\text { aplicação de provas de } \\
\text { concurso }\end{array}$ & \\
\hline $\begin{array}{l}\text { Pagamentos: Pagamento das equipes, Pagamentos diversos (espaço } \\
\text { físico, transporte, lanche etc) }\end{array}$ & $\begin{array}{l}\text { Pagamentos relacionados } \\
\text { a concursos }\end{array}$ & 1 \\
\hline $\begin{array}{l}\text { Conferência, processamento e batimento: Recebimento e abertura do } \\
\text { material; Leitura de atas/formulários de controle da aplicação; } \\
\text { Digitalização e interpretação; Batimento; Candidatos especiais; } \\
\text { Divulgação de gabarito provisório: Desenvolvimento de sistema de } \\
\text { recursos, Contratação de bancas; Revisão das respostas das bancas }\end{array}$ & $\begin{array}{l}\text { Procedimentos de } \\
\text { conferência, } \\
\text { processamento e } \\
\text { batimento }\end{array}$ & 1 \\
\hline $\begin{array}{l}\text { Correção (desenvolvimento de sistemas): Objetivas; Discursiva: } \\
\text { Treinamento de bancas para estabelecimento de padrão de respostas } \\
\text { esperado e correção da amostra, Digitalização dos textos e adaptação } \\
\text { do sistema, Divulgação de espelhos de correção e análise de recursos }\end{array}$ & $\begin{array}{l}\text { Procedimentos de } \\
\text { correção de provas de } \\
\text { concurso }\end{array}$ & 1 \\
\hline $\begin{array}{l}\text { Elaboração de editais de resultado final: Elaboração de relatórios } \\
\text { finais, Candidatos especiais, Candidatos sub-judice, Desenvolvimento } \\
\text { de sistemas de consulta de resultados, de cópias das folhas de } \\
\text { respostas/textos e de geração de boletim de desempenho }\end{array}$ & $\begin{array}{l}\text { Elaboração de editais de } \\
\text { resultado final }\end{array}$ & 1 \\
\hline Auditoria dos processos & Auditoria & 1 \\
\hline $\begin{array}{l}\text { Outras etapas possíveis: Avaliação de títulos, Prova oral, Defesa de } \\
\text { memorial, Prova prática, Prova de digitação, Avaliação psicológica, } \\
\text { Testes de capacidade física, Avaliação de vida pregressa, Exames } \\
\text { médicos, Cursos de formação }\end{array}$ & $\begin{array}{l}\text { "Outras etapas possíveis" } \\
\text { relacionadas a concursos }\end{array}$ & 1 \\
\hline \multicolumn{3}{|c|}{ TOTAL: 23} \\
\hline
\end{tabular}

\section{Categoria 2 - Pontos Fortes e Melhorias}

O entrevistado considera como pontos fortes do Cespe a qualidade dos instrumentos de avaliação, a organização e a segurança, "tanto nos processos internos quanto nos de logística de aplicação". Também considera o comprometimento dos funcionários como um aspecto muito positivo, bem como a "preocupação constante de garantir a isonomia nos procedimentos necessários às seleções" e a qualificação dos funcionários. No entanto, acredita que este último aspecto precisa ser intensificado, e o fato de o Cespe estar inserido em uma universidade viabiliza a melhora da qualidade do corpo técnico e dos procedimentos. Acredita, ainda, que é necessário "criar mecanismos que contribuam para melhorar o controle de todas as etapas e medir a segurança e fidedignidade da informação em cada uma delas", além de considerar necessários "sistemas de gerenciamento para melhorar a eficácia". Afirma que o Centro busca "oportunidades de contribuir com estados e municípios na indicação de políticas públicas de melhoria da qualidade da educação no país". Também acredita que "a consolidação de grupos de pesquisa também abre caminho para parcerias internacionais". 
Tabela 11 - Respondente 5 - Categoria 2 - Pontos fortes e melhorias

\begin{tabular}{|c|c|c|}
\hline Verbalização & Tema & Freq. \\
\hline $\begin{array}{l}\text { Devido à complexidade do processo, precisamos criar mecanismos } \\
\text { que contribuam para melhorar o controle de todas as etapas e medir a } \\
\text { segurança e fidedignidade da informação em cada uma delas. Isso é } \\
\text { fundamental nesse tipo de atividade. }\end{array}$ & "melhorar o controle" & 1 \\
\hline $\begin{array}{l}\text { Ainda necessitamos de sistemas de gerenciamento para melhorar a } \\
\text { eficácia. }\end{array}$ & $\begin{array}{l}\text { Sistemas de } \\
\text { gerenciamento }\end{array}$ & 1 \\
\hline $\begin{array}{l}\text { A capacitação dos colaboradores fixos do Centro precisa ser } \\
\text { intensificada para a melhoria da qualidade do serviço prestado. }\end{array}$ & $\begin{array}{l}\text { Capacitação de } \\
\text { colaboradores }\end{array}$ & 3 \\
\hline $\begin{array}{l}\text { O serviço público exige, cada vez mais, profissionais bem preparados } \\
\text { para atuar em suas respectivas áreas. }\end{array}$ & & \\
\hline $\begin{array}{l}\text { O fato de estarmos inseridos em uma instituição pública de ensino - a } \\
\text { Universidade de Brasília -, nos possibilita criar grupos de estudos } \\
\text { para propor novas formas de avaliação e de inovação tecnológica } \\
\text { aplicada aos processos seletivos. }\end{array}$ & & \\
\hline Qualidade dos instrumentos de avaliação & Instrumentos & 1 \\
\hline $\begin{array}{l}\text { organização e segurança são alguns dos pontos fortes. O CESPE/UnB } \\
\text { investiu muito nos procedimentos de segurança nos últimos anos, } \\
\text { tanto nos processos internos quanto nos de logística de aplicação. } \\
\text { Muitos foram publicizados e outros, por motivos óbvios, são mantidos } \\
\text { em segredo. A criação do software de embaralhamento de itens, a } \\
\text { desidentificação das folhas de respostas no momento da aplicação e a } \\
\text { divulgação das imagens das folhas de respostas dos candidatos via } \\
\text { Internet são bons exemplos desses procedimentos. }\end{array}$ & Organização e segurança & 1 \\
\hline $\begin{array}{l}\text { A área de pesquisa em avaliação tem crescido muito no Centro, que } \\
\text { criou uma 'massa crítica' de profissionais que hoje estão se } \\
\text { especializando em cursos de mestrado e doutorado. Isso nos leva a } \\
\text { buscar oportunidades de contribuir com estados e municípios na } \\
\text { indicação de políticas públicas de melhoria da qualidade da educação } \\
\text { no país. A consolidação de grupos de pesquisa também abre caminho } \\
\text { para parcerias internacionais. }\end{array}$ & Oportunidades & 1 \\
\hline $\begin{array}{l}\text { Profissionais comprometidos com a excelência no atendimento à } \\
\text { população e com a implementação e a consolidação de programas } \\
\text { voltados à melhoria da qualidade de vida dos cidadãos. O Centro de } \\
\text { Seleção e de Promoção de Eventos da Universidade de Brasília } \\
\text { (Cespe/UnB), que, em seus } 14 \text { anos de existência, já avaliou mais de } \\
20 \text { milhões de candidatos, tem orgulho de contribuir com a inserção } \\
\text { de boa parte desses cidadãos no setor. }\end{array}$ & Comprometimento & 1 \\
\hline $\begin{array}{l}\text { Temos trabalhado seriamente nessa direção, com a preocupação } \\
\text { constante de garantir a isonomia nos procedimentos necessários às } \\
\text { seleções, para que a competição seja justa e que resulte sempre na } \\
\text { classificação dos melhores. Cabe lembrar que a isonomia de } \\
\text { tratamento passa pelo esmero na logística, pela construção de } \\
\text { instrumentos de avaliação tecnicamente bem elaborados e } \\
\text { balanceados, pelo reforço na segurança de todo o processo e pelo } \\
\text { atendimento de qualidade que sempre deve ser dispensado aos } \\
\text { candidatos. }\end{array}$ & Procedimentos & 1 \\
\hline
\end{tabular}

\section{Categoria 1 - Perfil}

A entrevistada tem curso superior incompleto e ocupa o cargo de secretária no Cespe. Conta que sua área é responsável pelo atendimento ao cliente institucional "desde o 
contato inicial (...) até a entrega do produto final”. Relata que, para captar recursos, o Cespe realiza "prestação de diversos serviços à comunidade, em especial os relacionados à organização e à realização de concursos, processos seletivos, avaliações educacionais, eventos e cursos variados, além de planejar e executar vestibulares e de realizar, pioneiramente, o Programa de Avaliação Seriada (PAS)".

Tabela 12 - Respondente 6 - Categoria 1 - Perfil

\begin{tabular}{|l|l|c|}
\hline Verbalização & Tema & Freq. \\
\hline Secretária & Cargo no Cespe & 1 \\
\hline nível superior incompleto & Escolaridade & 1 \\
\hline $\begin{array}{l}\text { Prestação de diversos serviços à comunidade, em especial os } \\
\text { relacionados à organização e à realização de concursos, processos } \\
\text { seletivos, avaliaçães educacionais, eventos e cursos variados, além de } \\
\text { planejar e executar vestibulares e de realizar, pioneiramente, o } \\
\text { Programa de Avaliação Seriada (PAS). }\end{array}$ & $\begin{array}{l}\text { Serviços para captação de } \\
\text { recursos }\end{array}$ & 1 \\
\hline $\begin{array}{l}\text { Atendimento ao cliente institucional desde o contato inicial para a } \\
\text { contratação do CESPE/UnB até a entrega do produto final. } \\
\text { Negociação: elaboração de propostas, minutas de contrato, confecção } \\
\text { do processo de contratação e procedimentos para assinatura de } \\
\text { contratos. Execução: acompanhamento do processo, confecção de } \\
\text { editais, envio de editais aos clientes internos e externos. }\end{array}$ & Processos da área & 1 \\
\hline \multicolumn{2}{|c|}{ TOTAL: 4} \\
\hline
\end{tabular}

\section{Categoria 2 - Pontos Fortes e Melhorias}

A entrevistada acredita que o ponto forte de seu setor é a "disponibilidade de cooperação com outras áreas". Acredita, no entanto, que é necessária "maior interatividade, comunicação clara e objetiva entre as áreas". Além disto, acredita que as áreas devem conhecer melhor as "metodologias de trabalho de outras áreas".

Tabela 13 - Respondente 6 - Categoria 2 - Pontos fortes e melhorias

\begin{tabular}{|l|l|c|}
\hline Verbalização & Tema & Freq. \\
\hline $\begin{array}{l}\text { Maior interatividade, comunicação clara e objetiva entre as áreas } \\
\text { deste Centro }\end{array}$ & $\begin{array}{l}\text { Comunicação entre as } \\
\text { áreas }\end{array}$ & 1 \\
\hline conhecimento das metodologias de trabalho de outras áreas. & Metodologias & 1 \\
\hline Disponibilidade de cooperação com outras áreas. & Cooperação & 1 \\
\hline \multicolumn{2}{|c|}{ TOTAL: 3} \\
\hline
\end{tabular}

\section{Categoria 1 - Perfil}

O entrevistado tem duas especializações, "uma na área de Tecnoclogia da Informação (TI) e outra na área de gerência de pequenas empresas”. Ocupa o cargo de Analista de Sistemas no Cespe. Relata que os processos mais importantes de seu setor são "o 
estudo e análise de editais para a criação de sistemas on-line de inscrição, sistemas para consulta de resultados e sistema para a interposição de recursos", além de "sistemas de correção, que processam as notas e geram a classificação final dos candidatos" e "o atendimento a solicitações da assessoria de técnica (...) e da central de atendimento ao candidato". Conta que sua área é responsável por gerar informações, e está "presente em todas as etapas de todos os eventos". Relata que, para captar recursos, o Cespe oferece serviços como seleção de recursos humanos, avaliação de pessoas e "outras espécies de avaliações (docentes, processos e programas)".

Tabela 14 - Respondente 7 - Categoria 1 - Perfil

\begin{tabular}{|l|l|c|}
\hline Verbalização & Tema & Freq. \\
\hline Analista de Sistemas & Cargo no Cespe & 1 \\
\hline $\begin{array}{l}\text { Nível Superior. Tenho duas especializações (um na área de TI e outra } \\
\text { na área de Gerência de pequenas empresas) }\end{array}$ & Escolaridade & 1 \\
\hline $\begin{array}{l}\text { Seleção de recursos humanos para empresas de diversas espécies } \\
\text { (pública ou privada); Avaliação de pessoas em diversos estágios de } \\
\text { escolaridade (processos de aprendizagem); Outras espécies de } \\
\text { avaliação (docentes, processos e programas). }\end{array}$ & $\begin{array}{l}\text { Serviços para captação de } \\
\text { recursos }\end{array}$ & 1 \\
\hline $\begin{array}{l}\text { Não existe apenas um processo administrativo tido como carro chefe. } \\
\text { Na verdade existem vários, dentre os mais importantes podemos citar } \\
\text { o estudo e análise de editais para a criação de sistemas on-line de } \\
\text { inscrição, sistemas para consulta de resultados e sistemas para a } \\
\text { interposição de recursos. Além disso, existem ainda os sistemas de } \\
\text { correção, que processam as notas e geram a classificação final dos } \\
\text { candidatos. Outro processo muito comum é o atendimento a } \\
\text { solicitações da assessoria de técnica (pedidos de cunho jurídico) e da } \\
\text { central de atendimento ao candidato. }\end{array}$ & Processos da área & 2 \\
\hline $\begin{array}{l}\text { É uma área responsável por gerar informações no intuito de } \\
\text { possibilitar um maior conhecimento sobre fatos na tomada de decisões } \\
\text { (por parte da direção geral). Além disso, é a área presente em todas as } \\
\text { etapas de todos os eventos (desde a concepção do cadastro até o } \\
\text { momento de geração do resultado final). }\end{array}$ & & \\
\hline \multicolumn{2}{|c|}{} & \\
\hline
\end{tabular}

\section{Categoria 2 - Pontos Fortes e Melhorias}

O entrevistado acredita que a qualidade do atendimento do setor tende a aumentar. Acredita que são necessárias melhorias relacionadas aos prazos, que são considerados "incompatíveis com a nossa capacidade atual de atendimento", e o oferecimento de capacitação a distância, "compatível com a falta de horário fixo para a dedicação em algum tipo de curso em outra modalidade". Acredita que, por deter a informação, a área "deve ser bem valorizada pela alta administração". Acredita que o Cespe poderia, também, oferecer “seleções por computador". 
Tabela 15 - Respondente 7 - Categoria 2 - Pontos fortes e melhorias

\begin{tabular}{|c|c|c|}
\hline Verbalização & Tema & Freq. \\
\hline $\begin{array}{l}\text { Os processos, em diversas vezes, chegam com prazos curtos e às } \\
\text { vezes até incompatíveis com a nossa capacidade atual de atendimento. } \\
\text { Alguns deles podem ser solucionados com a criação de sistemas de } \\
\text { consulta (para os pedidos cotidianos e de certa forma homogêneos). } \\
\text { Por se tratar de uma área que está presente em todas as etapas de } \\
\text { praticamente todos os eventos, se algum atraso ocorre em outra área, } \\
\text { este acaba prejudicando o cumprimento de prazos. }\end{array}$ & Prazos & 1 \\
\hline $\begin{array}{l}\text { Creio que é uma área que detêm a informação e por isso deve ser bem } \\
\text { valorizada pela alta administração. }\end{array}$ & Valorização da área & 1 \\
\hline $\begin{array}{l}\text { Creio que a área deve continuar atendendo aos candidatos, aos } \\
\text { usuários internos do CESPE/UnB e também os clientes institucionais } \\
\text { com uma qualidade cada vez maior. }\end{array}$ & Qualidade do atendimento & 1 \\
\hline Acho que deveríamos ainda ter seleções por computador & Oportunidades & 1 \\
\hline $\begin{array}{l}\text { de repente uma equipe (com especialistas na área) de ensino a } \\
\text { distância para que o pessoal possa se reciclar (esta é uma tremenda } \\
\text { dificuldade nos dias atuais pela falta de tempo). A flexibilidade do } \\
\text { ensino a distância creio que é compatível com a falta de horário fixo } \\
\text { para a dedicação em algum tipo de curso em outra modalidade } \\
\text { (presencial, por exemplo). }\end{array}$ & Capacitação & 1 \\
\hline
\end{tabular}

\section{Categoria 1 - Perfil}

A entrevistada tem curso superior completo e ocupa o cargo de Secretária Executiva tanto na FUB como no Cespe. Acredita que a finalidade da instituição é "prestar diversos serviços à comunidade externa, em especial os relacionados à organização e à realização de concursos públicos, processos seletivos, avaliações educacionais e institucionais, pesquisas em geral, certificação e acreditação, eventos e cursos variados voltados à educação corporativa”, e é por meio destas atividades que capta recursos. Sua área é responsável por "atividade superior de natureza técnica e administrativa, que consiste no planejamento, organização, coordenação e controle das ações voltadas à gestão de orçamento, finanças, documentos, pessoal, material, patrimônio e serviços gerais".

Tabela 16 - Respondente 8 - Categoria 1 - Perfil

\begin{tabular}{|c|c|c|}
\hline Verbalização & Tema & Freq. \\
\hline Secretário Executivo & Cargo na FUB & 1 \\
\hline O mesmo & Cargo no Cespe & 1 \\
\hline Superior Completo & Escolaridade & 1 \\
\hline $\begin{array}{l}\text { O CESPE/UnB tem por finalidade, além de seus objetivos acadêmicos } \\
\text { de planejamento e execução dos processos de seleção e de ingresso de } \\
\text { estudantes na Universidade de Brasília, por meio do Vestibular e do } \\
\text { Programa de Avaliação Seriada/PAS, prestar diversos serviços à } \\
\text { comunidade externa, em especial os relacionados à organização e à } \\
\text { realização de concursos públicos, processos seletivos, avaliações } \\
\text { educacionais e institucionais, pesquisas em geral, certificação e }\end{array}$ & Finalidade do Cespe & 1 \\
\hline
\end{tabular}




\begin{tabular}{|l|l|c|}
\hline Verbalização & Tema & Freq. \\
\hline acreditação, eventos e cursos variados voltados à educação corporativa. & & \\
\hline $\begin{array}{l}\text { Atividade superior de natureza técnica e administrativa, que consiste no } \\
\text { planejamento, organização, coordenação e controle das ações voltadas à } \\
\text { gestão de orçamento, finanças, documentos, pessoal, material, } \\
\text { patrimônio e serviços gerais. }\end{array}$ & Processos da área & 1 \\
\hline \multicolumn{2}{|c|}{ TOTAL: 5 } \\
\hline
\end{tabular}

\section{Categoria 2 - Pontos Fortes e Melhorias}

A entrevistada cita como pontos fortes do Cespe sua capacidade de captação de recursos, a competência do corpo docente, a segurança dos processos e a qualidade dos produtos, e vê como oportunidade a possibilidade de aumentar a demanda de serviços e a capacidade de arrecadação. Por outro lado, acredita que é necessário maior foco no planejamento das atividades, além de "capacitação institucional de forma motivadora para melhoria do desempenho". Também acredita que são necessários maior "agilidade e apoio de unidades quanto ao atendimento aos pedidos e projetos", o aumento do quadro de servidores e uma infra-estrutura adequada às necessidades da instituição. Ela cita, ainda, o aumento da concorrência como uma ameaça, e a "demora na liberação do orçamento pelo Governo Federal" como um ponto fraco.

Tabela 17 - Respondente 8 - Categoria 2 - Pontos fortes e melhorias

\begin{tabular}{|l|l|c|}
\hline Verbalização & Tema & Freq. \\
\hline $\begin{array}{l}\text { Envolvimento e conscientização dos gestores e servidores quanto ao } \\
\text { planejamento das atividades }\end{array}$ & Planejamento & 1 \\
\hline $\begin{array}{l}\text { programa de capacitação institucional de forma motivadora para } \\
\text { melhoria do desempenho. }\end{array}$ & Capacitação & 2 \\
\hline $\begin{array}{l}\text { treinamento para servidores e técnico-administrativos; programa de } \\
\text { capacitação institucional de forma motivadora para melhoria do } \\
\text { desempenho }\end{array}$ & & 2 \\
\hline $\begin{array}{l}\text { Agilidade e apoio de unidades quanto ao atendimento aos pedidos e } \\
\text { projetos }\end{array}$ & Agilidade e apoio & 2 \\
\hline $\begin{array}{l}\text { Demora no atendimento de pedidos/serviços solicitados a outras } \\
\text { unidades; dificuldades na obtenção das informações para a elaboração e } \\
\text { operacionalização do planejamento da Unidade }\end{array}$ & & 5 \\
\hline Ampliação do quadro de servidores técnico-administrativos. & Quadro de servidores & \\
\hline Carência de capital humano especializado & & \\
\hline $\begin{array}{l}\text { Evasão e alta rotatividade de servidores, docentes e funcionários extra- } \\
\text { quadro }\end{array}$ & & \\
\hline Falta de perspectiva de reposição e ampliação do quadro de RH. & & \\
\hline Pessoal do quadro insuficiente. & Infra-estrutura & 3 \\
\hline Infra-estrutura física inadequada e/ou insuficiente & & \\
\hline dependência da construção de novos prédios & & \\
\hline Espaço físico inadequado recursos & \\
\hline Grande capacidade de captação de recursos. & & \\
\hline
\end{tabular}




\begin{tabular}{|l|l|c|}
\hline Verbalização & Tema & Freq. \\
\hline Competência instalada. Corpo docente qualificado e reconhecido. & Corpo docente & 1 \\
\hline Segurança dos processos. & Segurança & 1 \\
\hline Qualidade dos produtos & Qualidade & 1 \\
\hline $\begin{array}{l}\text { Aumento da demanda por serviços prestados; Ampliação da capacidade } \\
\text { de arrecadação }\end{array}$ & Oportunidades & 1 \\
\hline Aumento da concorrência técnica especializada. & Concorrência & 1 \\
\hline Demora na liberação do orçamento pelo Governo Federal. & Orçamento & 1 \\
\hline \multicolumn{2}{|l}{ TOTAL: 20 } \\
\hline
\end{tabular}

\section{Categoria 1 - Perfil}

A entrevistada tem curso superior completo e ocupa o cargo de Assistente Social na FUB e de Diretora Executiva no Cespe. Conta que o carro chefe da instituição é responder questionamentos dos candidatos e, para captar recursos, o Cespe realiza vestibular, concursos, avaliações, entre outros.

Tabela 18 - Respondente 9 - Categoria 1 - Perfil

\begin{tabular}{|l|l|c|}
\hline Verbalização & Tema & Freq. \\
\hline Assistente Social & Cargo na FUB & 1 \\
\hline Diretora Executiva & Cargo no Cespe & 1 \\
\hline Superior & Escolaridade & 1 \\
\hline Vestibular,Cursos,Concursos, Avaliações,outros esporadicamente. & $\begin{array}{l}\text { Serviços para captação } \\
\text { de recursos }\end{array}$ & 1 \\
\hline Responder questionamentos dos candidatos. & Carro chefe do Cespe & 1 \\
\hline \multicolumn{1}{|c|}{ TOTAL: 5 } \\
\hline
\end{tabular}

\section{Categoria 2 - Pontos Fortes e Melhorias}

A entrevistada acredita que é necessário melhorar a confecção dos editais e os serviços de atendimento ao candidato. Percebe a "avaliação institucional e de diversos processos" como uma oportunidade para o Cespe.

Tabela 19 - Respondente 9 - Categoria 2 - Pontos fortes e melhorias

\begin{tabular}{|l|l|c|}
\hline Verbalização & Tema & Freq. \\
\hline Melhorar a confecção dos editais & Editais & 1 \\
\hline serviços de atendimento aos candidatos. & Atendimento & 1 \\
\hline Avaliação institucional,e de diversos processos. & Oportunidades & 1 \\
\hline \multicolumn{2}{|c|}{ TOTAL: 3} \\
\hline
\end{tabular}




\section{Categoria 1 - Perfil}

O entrevistado tem ensino médio completo e ocupa o cargo de Vigilante na FUB e de Assistente em Administração no Cespe. Sua área é responsável por "cadastro de colaboradores interno e externo, cadastro de bancos e agencias, controle de freqüência de colaboradores eventuais, atendimento ao publico pessoalmente, por telefone e email, analises de planilhas e contratos pra pagamento, elaboração, analise e finalização de folha de pagamento, elaboração e fechamento de lista de credor para pagamento". Ele afirma que, para captar recursos, o Cespe realiza "aplicação do vestibular e PAS, aplicação de concursos em todas as fases, avaliações diversas (...), seminários e congressos".

Tabela 20 - Respondente 10 - Categoria 1 - Perfil

\begin{tabular}{|c|c|c|}
\hline Verbalização & Tema & Freq. \\
\hline Vigilante & Cargo na FUB & 1 \\
\hline Assistente em Administração & Cargo no Cespe & 1 \\
\hline $2^{\circ}$ grau completo & Escolaridade & 1 \\
\hline $\begin{array}{l}\text { Aplicação do vestibular e PAS, aplicação de concursos em todas as } \\
\text { fases, avaliações diversas (ENEM, ENADE, TV Escola, Escola Aberta } \\
\text { etc.), seminários e congressos }\end{array}$ & $\begin{array}{l}\text { Serviços para captação } \\
\text { de recursos }\end{array}$ & 1 \\
\hline $\begin{array}{l}\text { Cadastro de colaboradores interno e externo, Cadastro de bancos e } \\
\text { agencias, controle de freqüência de colaboradores eventuais, } \\
\text { Atendimento ao publico pessoalmente, por telefone e email, Analises de } \\
\text { planilhas e contratos pra pagamento, Elaboração, analise e finalização } \\
\text { de folha de pagamento, Elaboração e fechamento de lista de credor para } \\
\text { pagamento }\end{array}$ & Processos da área & 1 \\
\hline \multicolumn{3}{|c|}{ TOTAL: 5} \\
\hline
\end{tabular}

\section{Categoria 2 - Pontos Fortes e Melhorias}

O entrevistado afirma que os pontos fortes do Cespe são o "material humano", o cumprimento dos prazos de pagamento e a agilidade para resolver problemas. No entanto, acredita que é preciso "modernizar os procedimentos com novas tecnologias e metodologias", e promover maior interação entre as áreas. Como oportunidade, acredita que a instituição pode "vir um dia poder fazer pagamento pra outros órgãos e empresas que não dispõe desse serviço".

Tabela 21 - Respondente 10 - Categoria 2 - Pontos fortes e melhorias

\begin{tabular}{|l|l|c|}
\hline Verbalização & Tema & Freq. \\
\hline $\begin{array}{l}\text { Modernizar os procedimentos com novas tecnologia e metodologias } \\
\text { para agilizar com eficácia os processos. }\end{array}$ & $\begin{array}{l}\text { Tecnologia e } \\
\text { metodologias }\end{array}$ & 1 \\
\hline Maior interação com as áreas afins. & Interação & 1 \\
\hline Material humano & Funcionários & 1 \\
\hline
\end{tabular}




\begin{tabular}{|l|l|c|}
\hline Cumprimento dos prazos de pagamento & Prazos & 1 \\
\hline Agilidade em resolver os problemas que surgem. & Agilidade & 1 \\
\hline $\begin{array}{l}\text { Vir um dia poder fazer pagamento pra outros órgãos e empresas que não } \\
\text { dispõe desse serviço. }\end{array}$ & Oportunidade & 1 \\
\hline \multicolumn{2}{|l|}{} & \multicolumn{2}{|c|}{ TOTAL: 6 } \\
\hline
\end{tabular}

\section{Categoria 1 - Perfil}

O entrevistado tem doutorado e ocupa o cargo de Professor na FUB e de Coordenador de Pesquisa em Avaliação no Cespe. Conta que "o principal processo associado à área é o de gestão do conhecimento". Afirma que, para captar recursos, o Cespe realiza seleções, avaliações de sistemas educacionais, certificação e proficiência em línguas.

Tabela 22 - Respondente 11 - Categoria 1 - Perfil

\begin{tabular}{|l|l|c|}
\hline Verbalização & Tema & Freq. \\
\hline Professor & Cargo na FUB & 1 \\
\hline Coordenador de Pesquisa em Avaliação & Cargo no Cespe & 1 \\
\hline Doutorado & Escolaridade & 1 \\
\hline $\begin{array}{l}\text { Seleção de pessoas para ocupar cargos públicos, avaliação de sistemas } \\
\text { educacionais, certificação e proficiência em línguas. }\end{array}$ & $\begin{array}{l}\text { Serviços para captação } \\
\text { de recursos }\end{array}$ & 1 \\
\hline $\begin{array}{l}\text { O principal processo associado à área é o de gestão do conhecimento. } \\
\text { Todos os trabalhos do setor exigem conhecimento: este é o carro chefe } \\
\text { do setor. }\end{array}$ & Processos do setor & 1 \\
\hline \multicolumn{2}{|c|}{ TOTAL: 5 } \\
\hline
\end{tabular}

\section{Categoria 2 - Pontos Fortes e Melhorias}

O entrevistado considera como ponto forte "o domínio de métodos e tecnologias pouco dominadas no país". Acredita que é importante melhorar o processo "com ferramentas de gestão do conhecimento, que ainda são bastante escassas". Como oportunidade, percebe "a área de certificação profissional, que ainda é muito pouco explorada e dominada no país".

Tabela 23 - Respondente 11 - Categoria 2 - Pontos fortes e melhorias

\begin{tabular}{|l|l|c|}
\hline Verbalização & Tema & Freq. \\
\hline $\begin{array}{l}\text { O processo pode ser melhorado com ferramentas de gestão do } \\
\text { conhecimento, que ainda são bastante escassas. }\end{array}$ & $\begin{array}{l}\text { Gestão do } \\
\text { conhecimento }\end{array}$ & 1 \\
\hline $\begin{array}{l}\text { O domínio de métodos e tecnologias pouco dominados no país: Teoria } \\
\text { de Resposta ao Itens e a tecnologia Computer Adaptative Tests. }\end{array}$ & Metodologias & 1 \\
\hline $\begin{array}{l}\text { A área de certificação profissional que é ainda muito pouco explorada e } \\
\text { dominada no país. }\end{array}$ & Oportunidade & 1 \\
\hline \multicolumn{2}{|c|}{ TOTAL: 3 } \\
\hline
\end{tabular}




\section{Categoria 1 - Perfil}

O entrevistado tem curso superior e ocupa o cargo de secretário executivo na FUB e de revisor no Cespe. Sua área é responsável pela "produção de provas (...), incluindo contratação de bancas, revisão, editoração e liberação para impressão". Conta que, para captar recursos, o Cespe realiza processos de seleção e avaliação e eventos.

Tabela 24 - Respondente 12 - Categoria 1 - Perfil

\begin{tabular}{|l|l|c|}
\hline Verbalização & Tema & Freq. \\
\hline Secretário executivo & Cargo na FUB & 1 \\
\hline Revisor & Cargo no Cespe & 1 \\
\hline Nível superior & Escolaridade & 1 \\
\hline $\begin{array}{l}\text { Processos de seleç̃a e de avaliação (produção e aplicação de } \\
\text { instrumentos de avaliação), eventos (cursos de formação, treinamentos, } \\
\text { conferências) }\end{array}$ & $\begin{array}{l}\text { Serviços para captação } \\
\text { de recursos }\end{array}$ & 1 \\
\hline $\begin{array}{l}\text { Produção de provas para os mais diversos órgãos - concursos, seleções e } \\
\text { avaliações -, incluindo contratação de bancas, revisão, editoração e } \\
\text { liberação para impressão }\end{array}$ & Processos da área & 1 \\
\hline \multicolumn{2}{|c|}{} & \multicolumn{1}{|c|}{ TOTAL: 5 } \\
\hline
\end{tabular}

\section{Categoria 2 - Pontos Fortes e Melhorias}

O entrevistado considera como pontos fortes e flexibilidade e "a convivência quase sempre harmoniosa". Acredita que é necessário conscientizar os colaboradores para a necessidade de se economizar recursos. Percebe, como oportunidades a possibilidade de convênios com organismos internacionais e de oferecimento de treinamentos para grandes empresas.

Tabela 25 - Respondente 12 - Categoria 2 - Pontos fortes e melhorias

\begin{tabular}{|l|l|c|}
\hline Verbalização & Tema & Freq. \\
\hline $\begin{array}{l}\text { No treinamento de diversos colaboradores envolvidos, focado em corte } \\
\text { de "custos visíveis". Tenho a impressão de que gastamos muito e mal. É } \\
\text { preciso "investir" mais na implementação de "checklists" e na } \\
\text { conscientização, inclusive ambiental, quanto à necessidade de } \\
\text { economizar - papel, tôner, tintas, energia elétrica, água, telefone }\end{array}$ & Economia & 1 \\
\hline Flexibilidade para atuação em diferentes tarefas & Flexibilidade & 1 \\
\hline principalmente, para a convivência quase sempre harmoniosa & Convivência & 1 \\
\hline $\begin{array}{l}\text { Convênios com organismos internacionais para gerenciamento da } \\
\text { execução de projetos no Brasil }\end{array}$ & Convênios & 1 \\
\hline $\begin{array}{l}\text { Oferecimento de cursos para treinamento/reciclagem para grupos de } \\
\text { empregados de grandes empresas - construtoras, metrô, grandes lojas, } \\
\text { bancos privados, etc. }\end{array}$ & Treinamento & 1 \\
\hline \multicolumn{2}{|c|}{} & TOTAL: 5 \\
\hline
\end{tabular}




\section{Categoria 1 - Perfil}

O entrevistado tem curso superior completo e ocupa o cargo de docente na FUB e de revisor no Cespe. Atua na coordenadoria acadêmica, responsável pela "laboração de itens, questões objetivas e discursivas para concursos públicos e processos avaliativos". Afirma que, para captar recursos, o Cespe oferece serviços tais como "aplicação de concursos públicos, condução de processos avaliativos, assessorias”.

Tabela 26 - Respondente 13 - Categoria 1 - Perfil

\begin{tabular}{|l|l|c|}
\hline Verbalização & Tema & Freq. \\
\hline Docente & Cargo na FUB & 1 \\
\hline Revisor & Cargo no Cespe & 1 \\
\hline Coordenadoria acadêmica & Setor & 1 \\
\hline Terceiro grau & Escolaridade & 1 \\
\hline $\begin{array}{l}\text { Aplicação de concursos públicos, condução de processos avaliativos, } \\
\text { assessorias }\end{array}$ & $\begin{array}{l}\text { Serviços para captação } \\
\text { de recursos }\end{array}$ & 1 \\
\hline $\begin{array}{l}\text { Elaboração de itens, questões objetivas e discursivas para concursos } \\
\text { públicos e processos avaliativos }\end{array}$ & Processos da área & 1 \\
\hline \multicolumn{2}{|c|}{ TOTAL: 6 } \\
\hline
\end{tabular}

O entrevistado considera a equipe do Cespe, por sua capacidade e empenho, como o ponto forte da instituição. Acredita, no entanto, que é necessária a "implantação de um sistema corriqueiro de controle da qualidade das questões, itens elaborados". Acredita que "a maior oportunidade de o Cespe/UnB crescer em nível nacional ou até mesmo internacional consiste nos processos avaliativos, que têm sido intensificados nos últimos anos em nível mundial". Entretanto, acredita que o aumento da concorrência na área de concursos públicos tende a reduzir sua participação nesta área.

Tabela 27 - Respondente 13 - Categoria 2 - Pontos fortes e melhorias

\begin{tabular}{|l|l|c|}
\hline Verbalização & Tema & Freq. \\
\hline $\begin{array}{l}\text { Implantação de um sistema corriqueiro de controle da qualidade das } \\
\text { questões, itens elaborados, mediante aferição do índice de discriminação } \\
\text { após aplicação das mesmas. }\end{array}$ & $\begin{array}{l}\text { Controle da qualidade } \\
\text { das questões }\end{array}$ & 1 \\
\hline $\begin{array}{l}\text { O principal ponto forte da coordenadoria acadêmica consiste na } \\
\text { qualidade e empenho da equipe profissional que compõe o setor. }\end{array}$ & Equipe & 1 \\
\hline $\begin{array}{l}\text { No meu entender, a maior oportunidade de o Cespe/UnB crescer em } \\
\text { nível nacional ou até mesmo internacional consiste nos processos } \\
\text { avaliativos, que têm sido intensificados nos últimos anos em nível } \\
\text { mundial. A estrutura, tradição e experiência acumuladas pelo }\end{array}$ & Oportunidade \\
$\begin{array}{l}\text { Cespe/UnB nos últimos anos nessa área o capacitam perfeitamente para } \\
\text { essas atividades. }\end{array}$ & \\
\hline $\begin{array}{l}\text { Por outro lado, a entrada de várias empresas particulares, muitas vezes } \\
\text { de pequeno porte, na área de concursos públicos tende, a meu ver, a } \\
\text { reduzir a participação do Cespe/UnB em concursos públicos nos anos } \\
\text { vindouros. }\end{array}$ & Concorrência & 1 \\
\hline \multicolumn{2}{|l|}{} & \\
\hline
\end{tabular}




\subsubsection{Resultados}

\section{Categoria 01 - Perfil}

Os entrevistados, em sua maioria, são funcionários da FUB que atuam no Cespe. Na maioria dos casos, a função exercida no Cespe é diferente do cargo ocupado na FUB. Foram entrevistados funcionários que exercem funções diversas, desde revisor, técnico em assuntos educacionais, passando por gerente, coordenador de pesquisa em avaliação, até diretor e diretor-geral. A maior parte dos funcionários entrevistados tem curso superior completo, muitos com pós-graduação, seja em nível de especialização, mestrado ou doutorado. As áreas em que atuam têm atividades diversas, como elaboração de itens, produção de provas, atendimento ao cliente e atividades administrativas, por exemplo. A grande maioria dos entrevistados relata que a captação de recursos é feita por meio do oferecimento de serviços tais como concursos e seleções, cursos de capacitação e formação e avaliação educacional.

\section{Temas: Cargo na FUB}

\section{Função no Cespe}

Escolaridade

Processos da área

Serviços oferecidos para capacitação de recursos

\section{Verbalizações:}

"Revisor"

"Superior Completo - Doutorado"

"Nível Superior. Tenho duas especializações (um na área de TI e outra na área de Gerência de pequenas empresas)"

\section{"Programador de Computador"}

"Atividade superior de natureza técnica e administrativa, que consiste no planejamento, organização, coordenação e controle das ações voltadas à gestão de orçamento, finanças, documentos, pessoal, material, patrimônio e serviços gerais."

"Elaboração de itens, questões objetivas e discursivas para concursos públicos e processos avaliativos"

"Prestação de diversos serviços à comunidade, em especial os relacionados à organização e à realização de concursos, processos seletivos, avaliações educacionais, eventos e cursos variados, além de planejar e executar vestibulares e de realizar, pioneiramente, o Programa de Avaliação Seriada" 
“Aplicação de concursos públicos, condução de processos avaliativos, assessorias”

\section{Categoria 02 - Pontos Fortes e Melhorias}

Grande parte dos entrevistados relata que a convivência e o trabalho em equipe são bons. Por outro lado, alguns acreditam que a integração e o apoio entre as equipes poderiam ser intensificados. A capacitação dos funcionários é citada por alguns dos entrevistados como algo a ser melhorado, enquanto uma parcela maior destaca este aspecto como um ponto forte. O corpo técnico é citado por alguns dos entrevistados como um ponto forte devido à sua capacidade técnica e comprometimento. No entanto, também há relatos de que a quantidade é insuficiente para a demanda de trabalho. A qualidade tanto do atendimento como dos processos e produtos e a segurança dos procedimentos são ressaltadas por uma parte dos entrevistados, mas outros relatam a necessidade de se atualizar metodologias e tecnologias e aprimorar processos. Também é destacada a necessidade de se aumentar o foco no planejamento. Em relação às oportunidades, são citadas possíveis parcerias internacionais e a expansão de serviços já existentes. Alguns entrevistados se referiram à concorrência como uma ameaça em relação a alguns serviços oferecidos.

Temas: Convivência e Trabalho em Equipe Planejamento

$\begin{array}{lc}\text { Capacitação } & \text { Tecnologia } \\ \text { Funcionários } & \text { Segurança } \\ \text { Qualidade de atendimento, processos e produtos } & \text { Oportunidades } \\ \text { Comprometimento } & \text { Concorrência }\end{array}$

\section{Verbalizações:}

"A área de pesquisa em avaliação tem crescido muito no Centro, que criou uma 'massa crítica' de profissionais que hoje estão se especializando em cursos de mestrado e doutorado. Isso nos leva a buscar oportunidades de contribuir com estados e municípios na indicação de políticas públicas de melhoria da qualidade da educação no país. A consolidação de grupos de pesquisa também abre caminho para parcerias internacionais."

"Segurança dos processos."

"Podem ser melhorados com mais investimento na parte tecnológica e pessoal especializado em programação" 
"Profissionais comprometidos com a excelência no atendimento à população e com a implementação e a consolidação de programas voltados à melhoria da qualidade de vida dos cidadãos."

"Qualidade dos produtos"

“Temos trabalhado seriamente nessa direção, com a preocupação constante de garantir a isonomia nos procedimentos necessários às seleções, para que a competição seja justa e que resulte sempre na classificação dos melhores."

"Convênios com organismos internacionais para gerenciamento da execução de projetos no Brasil"

"A capacitação dos colaboradores fixos do Centro precisa ser intensificada para a melhoria da qualidade do serviço prestado."

"Buscar sempre a melhor a formalização dos processos, com vistas à atender satisfatoriamente as exigências dos órgãos de controle."

"Carência de capital humano especializado"

"Planejamento de modo geral nas atividades desenvolvidas pelo órgão."

"Competência instalada. Corpo docente qualificado e reconhecido."

"Por outro lado, a entrada de várias empresas particulares, muitas vezes de pequeno porte, na área de concursos públicos tende, a meu ver, a reduzir a participação do Cespe/UnB em concursos públicos nos anos vindouros."

"Maior interatividade, comunicação clara e objetiva entre as áreas deste Centro"

"Aumento da concorrência técnica especializada."

“Também é muito positivo o intercâmbio com pesquisadores e o trabalho em equipe." 


\section{CONSIDERAÇÕES FINAIS}

O presente trabalho pretendeu, no âmbito do conhecimento, iniciar uma discussão doutrinária, legal e jurisprudencial acerca do tema estudado, e também, discutir propostas de melhoria dos processos e procedimentos administrativos, além de salientar a importância dos processos desenvolvidos para a sociedade brasileira e mais especificamente para a brasiliense.

A crise institucional financeira das universidades públicas nos anos noventa ensejou a busca de recursos por meio da prestação de serviços. No Brasil, as instituições de ensino superior públicas foram estimuladas a captar recursos próprios para complementar as verbas repassadas pelo governo, ocasião em que surgiram as fundações de apoio. No caso específico da UnB, além das fundações, nasce o CESPE/UnB, Centro sem personalidade jurídica própria, ligado ao gabinete do Reitor que, em médio prazo, tornou-se o maior captador de recursos próprios da Universidade.

A dependência de recursos para a manutenção e desenvolvimento da UnB é crescente. Segundo o Relatório Preliminar de Gestão de 2007, disponível no Portal da Universidade, nos últimos cinco anos os recursos diretamente arrecadados foram equivalentes a mais que o triplo dos aportados pelo MEC, para despesas correntes. Hoje, conhecido nacional e internacionalmente, o CESPE/UnB é sempre lembrado em todas as crises políticas, seja no debate sobre o ensino superior público e gratuito ou sobre o autofinancimento, com forte reação contrária à proposta considerada neoliberal. Questionam sua regularidade, seus dirigentes, seu papel na sociedade e a excelência do nível dos serviços prestados.

Sem a pretensão de esgotar o tema sobre prestação de serviços pelo CESPE/UnB à sociedade, o caráter interdisciplinar fica evidenciado pelo estudo da legislação aplicada e também pelos procedimentos de gestão administrativa, constituindo-se em possível material de consulta aos gestores públicos e de referência teórica para outras instituições.

A pesquisa documental permitiu certificar que o referido Centro adota planejamento das atividades com previsão de recursos para cobrir despesas de cada etapa dos processos, sendo a mais relevante a inerente ao pagamento de pessoas físicas, internas e externas à FUB. Verificou-se que esses pagamentos estão devidamente regulamentados em normas internas e que atendem à legislação federal e à jurisprudência do TCU. 
O estudo do referencial teórico e dos documentos institucionais indicam a importância do CESPE para a UnB. Os diagnósticos realizados na instituição apontam a necessidade de modernização da gestão e dos processos desenvolvidos pela Universidade, inclusive dos desenvolvidos pelo próprio Centro.

Verificou-se ainda, que a sua estrutura formal vem sendo questionada recorrentemente pelos órgãos de controle. Na realidade, a estrutura é burocrática e rígida, o que torna o modelo de gestão inadequado. O fluxo dos procedimentos inclui fases diferentes para cada processo, em razão do grau de complexidade, o que requer uma organização dinâmica e constantemente aperfeiçoada. A atual gestão adotou mecanismos gerenciais que contemplam parte das recomendações dos órgãos de controle, até que o processo de reestruturação institucional seja concluído pela área técnica e aprovado pelos conselhos superiores.

Os resultados da pesquisa - em face da população-alvo entrevistada e pelos itens respondidos - revelaram a importância dos trabalhos executados pelo CESPE/UnB, o comprometimento da equipe e a qualidade dos serviços. As manifestações demonstram pessoas entusiasmadas pelas atividades que desenvolvem e que sentem satisfação em contribuir com os processos realizados em prol da melhoria da qualidade do ensino no país e da qualidade de vida dos cidadãos. Ao mesmo tempo, sugerem melhoria nas ações de planejamento, capacitação de pessoal, investimento em tecnologia e interatividade entre as áreas.

A pesquisa abrangeu aspectos qualitativos e os resultados propõem aprofundamento dos estudos em relação ao modelo de gestão e à estruturação dos processos.

A partir dessas premissas, contextualizadas com o referencial teórico apresentado, pode-se inferir que nos últimos anos o CESPE/UnB teve um vertiginoso crescimento na execução de seus processos com conseqüente aumento de recursos arrecadados, os quais são imprescindíveis à complementação dos recursos para manutenção da Universidade.

Verifica-se que os processos executados são revestidos de total segurança jurídica aos seus gestores, que utilizam-se dos procedimentos necessários à consecução dos objetivos institucionais do Centro, mediante a aplicação e o acatamento à legislação pertinente e à regulamentação interna da FUB, além de atender às recomendações dos órgãos de controle.

No entanto, o modelo de gestão não acompanhou esse processo, principalmente em relação à utilização das modernas tecnologias de informação, disponíveis no mercado e na 
própria instituição. O crescimento exige a implantação de um novo sistema de gestão que maximize a utilização de recursos disponíveis na $U n B$, reduzindo, com isso, o custo dos processos, principalmente aqueles relacionados ao pagamento de pessoal. É importante destacar que a definição de um novo modelo de gestão tem como fundamento a mudança cultural da gestão administrativa e, consequientemente, dos processos e ferramentas de apoio, como os sistemas de informação.

É recomendável, ainda, a elaboração de um regimento interno que discipline o poder de decisão e a revisão das normas de estrutura organizacional, com a implantação da gestão por processos e a implantação de plataforma integrada para a gestão administrativa do Centro. O tratamento dinâmico da gestão garantirá seu padrão de competitividade, sua capacidade de satisfazer as necessidades internas e as expectativas dos clientes e cidadãos aos quais serve de acordo com a sua missão e com os preceitos legais a que está submetido. 


\section{REFERÊNCIAS}

ALEXANDRINO, M; PAULO, V. Direito Administrativo. 9ª . ed. Rio de Janeiro: Impetus, 2005.

BARDIN, L. Análise de conteúdo. Lisboa: Edições 70, 1977.

BRASIL. Constituição (1988).Lex: legislação federal, Presidência da República, abril. 2008.

BRASIL. Decreto-Lei no. 200, de 25 de fevereiro de 1967.Lex: legislação federal, Presidência da República, abril. 2008.

BRASIL. Lei no. 7.596, de 10 de abril de 1987. Lex: legislação federal, Presidência da República, abril. 2008.

BRASIL. Ministério do Planejamento, Orçamento e Gestão. Secretaria de Orçamento Federal. Orçamento da União exercício financeiro 2006. Lei n. 11.306, de 16 de maio de 2006, v. 5, Brasília, $2006 . \quad$ Disponível em: <http://www.planejamento.gov.br/orcamento/conteudo/orcamento_anteriores.htm>, Acesso em: 12 jun2008.

FRANCO, M.L.P.B, As categorias de análise. In: Análise de Conteúdo. Brasília: Plano Editora, 2003. Cap.6.

FREITAS, H; OLIVEIRA, M; SACCOL, A; MOSCAROLA, J. O método de pesquisa survey. Revista de Administração, São Paulo, v. 35, n. 3, p. 105-112, jul./set. 2000.

FUB. Ato da Reitoria $\mathrm{n}^{\mathrm{o}} 1.654$, de 30 de dezembro de 2005.

HENRIQUES, A. M. D.; MALHEIROS, T. M. (Org.) A Universidade de Brasília e suas Fundações de Apoio: Aspectos Legais e Administrativos. In: Seminário, 1, 2002, Brasília: FINATEC, 2002.

GIL, A. C. Entrevista. In: Métodos e Técnicas de Pesquisa Social. 5.ed. São Paulo: Atlas, 1999.cap. 11.

GÜNTER, H. Desenvolvimento de Instrumento para levantamento de dados. In: Pasquali, L. (Org). Teoria e métodos de medida em ciências do comportamento. Brasília: UnB-INEP, 1996. Cap.15. p. 387-403.

MARCELINO, G. O processo de administração estratégica da FA. In: VULCÃO, M; MIRANDA, N; DAVID, ; MARCELINO, G. (Org.) Gestão Estratégica de Universidade: o caso da FA/UnB. Brasília: EDU, 2003. p. 141-155.

MEIRELLES, H.L. Direito Administrativo Brasileiro. In: Administração Pública. 24 ${ }^{\mathrm{a}}$ Ed. São Paulo: Malheiros, 1999. Cap. 2.

MORIN, E. Os Sete Saberes necessários à Educação do Futuro. 12ª . ed. São Paulo: Cortez, 2007. 
PAES, J. E. S. Fundações e Entidades de Interesse Social: Aspectos jurídicos, administrativos, contábeis e tributários. 4ª . ed. Brasília: Brasília Jurídica, 2003.

RAMOS, S. Parecer SR-78, da Consultoria-Geral da República, de 15 de dezembro de 1988, publicado no DO de 16/12/88, Seção I, pp. 24582-24585

SAMPAIO, A. L. B. Autonomia universitária da doutrina brasileira. In: Autonomia Universitária: um modelo de interpretação e aplicação do artigo 207 da Constituição Federal. Brasília: Universidade de Brasília, 1998. Cap. III, pág. 88-120.

SANTOS, B. S. A Universidade no Século XXI: Para uma reforma democrática e emancipatória da Universidade. $2^{a}$. ed. São Paulo: Cortez, 2005.

SILVA, O. D. Palestra proferida no II Simpósio Multidisciplinar. A Integração Universidade-Comunidade. São Paulo: USJT, 1996. Disponível em:

<http://www.ecientificocultural.com/ECC2/artigos/oberdan9.html\#Rodapé>, Acesso em: 24 jun2008.

SGUISSARDI, V. Reforma Universitária no Brasil - 1996 -2006: Precária trajetória e incerto futuro. Educação Soc., Campinas Vol.27, n. 96 - Especial, p. 1021 - 1056, out. 2006.

VELLOSO, J.; MARQUES, P.M. Recursos próprios da UnB, o financiamento das IFES e a reforma da educação superior. Educação Social, Campinas, v. 26, n. 91, p.655-680, maio/ago. 2005.

UnB. UNIVERSIDADE DE BRASÍLIA. Secretaria de Planejamento. Relatório Preliminar de Gestão 2007. Brasilia, 2007.

UnB. UNIVERSIDADE DE BRASÍLIA. Secretaria de Planejamento. Bases estratégicas para o PDI 2007-2010. Brasília, 2007. 
ANEXO 


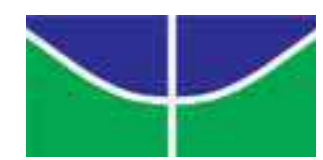

UNIVERSIDADE DE BRASÍLIA

FACULDADE DE ECONOMIA, ADMINISTRAÇÃO, CONTABILIDADE E CIÊNCIA DA INFORMAÇÃO E DOCUMENTAÇÃO (FACE)

\section{ENTREVISTA}

\section{Campo A}

1 Nome:

2 Cargo que ocupa na FUB:

3 Cargo que ocupa no CESPE:

4 Escolaridade:

\section{Campo B}

5 Quais são os serviços oferecidos pelo CESPE/UnB à sociedade que garantem a captação de recursos complementares para UnB?

6 Descreva o processo administrativo tido como o carro chefe de sua área.

7 Em que podem ser melhorados os procedimentos relativos ao processo administrativo descrito?

8 Quais são os pontos fortes da sua área?

9 Quais as oportunidades vislumbradas pela área, no contexto nacional, nas quais o CESPE/UnB pode atuar?

10 Quero acrescentar... 